\title{
Spatial quality control bypasses cell-based limitations on proteostasis to promote prion curing
}

\author{
Courtney L Klaips ${ }^{1,2 \pi}$, Megan L Hochstrasser ${ }^{1+\ddagger}$, Christine R Langlois $^{1 \dagger}$, \\ Tricia R Serio ${ }^{2 *}$
}

'Department of Molecular Biology, Cell Biology and Biochemistry, Brown University, Providence, United States; ${ }^{2}$ Department of Molecular and Cellular Biology, University of Arizona, Tucson, United States

*For correspondence: tserio@ email.arizona.edu

†These authors contributed equally to this work

Present address: "Max Planck Institute of Biochemistry, Munich, Germany; ‘Department of Molecular and Cell Biology, University of California, Berkeley, Berkeley, United States

Competing interests: The authors declare that no competing interests exist.

Funding: See page 20

Received: 08 August 2014 Accepted: 23 October 2014 Published: 09 December 2014

Reviewing editor: Jeffery W Kelly, Scripps Research Institute, United States

(c) Copyright Klaips et al. This article is distributed under the terms of the Creative Commons Attribution License, which permits unrestricted use and redistribution provided that the original author and source are credited.

\begin{abstract}
The proteostasis network has evolved to support protein folding under normal conditions and to expand this capacity in response to proteotoxic stresses. Nevertheless, many pathogenic states are associated with protein misfolding, revealing in vivo limitations on quality control mechanisms. One contributor to these limitations is the physical characteristics of misfolded proteins, as exemplified by amyloids, which are largely resistant to clearance. However, other limitations imposed by the cellular environment are poorly understood. To identify cell-based restrictions on proteostasis capacity, we determined the mechanism by which thermal stress cures the $\left[\mathrm{PSI}^{+}\right] / \mathrm{Sup} 35$ prion. Remarkably, Sup35 amyloid is disassembled at elevated temperatures by the molecular chaperone Hsp104. This process requires Hsp104 engagement with heat-induced non-prion aggregates in late cell-cycle stage cells, which promotes its asymmetric retention and thereby effective activity. Thus, cell division imposes a potent limitation on proteostasis capacity that can be bypassed by the spatial engagement of a quality control factor.
\end{abstract}

DOI: 10.7554/eLife.04288.001

\section{Introduction}

The proper folding of proteins is essential to cellular homeostasis, and an extensive collection of protein quality control (POC) pathways, known as the proteostasis network, has evolved to protect nascent and metastable proteins from misfolding and to reactivate or remove proteins that have already misfolded (Powers et al., 2009; Wolff et al., 2014). The PQC network is tailored to buffer protein folding in a distinct homeostatic niche but can adapt when these buffering thresholds are exceeded by elevating the expression of POC factors, including proteases and molecular chaperones, to clear accumulating misfolded proteins (Morimoto, 2008; Powers et al., 2009). In cases such as thermal stress, these corrections are sufficient to restore balance, but in others such as aging, misfolded proteins assemble into ordered amyloid aggregates, which persist and dramatically alter cellular physiology by inducing disease (Tuite and Serio, 2010; Voisine et al., 2010; Taylor and Dillin, 2011; Kim et al., 2013). This proteostasis collapse has been linked to the unique ability of amyloids to incorporate and conformationally convert like protein to the misfolded state and to their high thermodynamic stability (Chiti and Dobson, 2006; Jahn and Radford, 2008). Together, these properties are thought to enhance the production and restrict the resolution of the misfolded protein to the point that the buffering capacity and adaptability of the proteostasis network is chronically exceeded.

Despite this natural upper boundary on proteostasis capacity, the heterologous overexpression of molecular chaperones in Caenorhabditis elegans, mice, Drosophila, yeast, and tissue culture-cell models of amyloidoses reduces proteotoxicity (Chernoff et al., 1995; Morimoto, 2008; Broadley and Hartl, 2009; Holmes et al., 2014). While these observations are often interpreted as evidence of 
eLife digest Proteins must fold into specific shapes to work inside cells, and the misfolding of proteins is associated with a growing number of diseases. For example, prions are misfolded proteins that form insoluble aggregates called amyloids. These aggregates are not easily destroyed and can cause other nearby proteins to misfold and join the amyloid. This process of amyloid assembly leads to progressive diseases such as mad cow disease, Huntington's disease, Alzheimer's disease, and Parkinson's disease, which are collectively known as amyloidoses.

A series of biological pathways called the proteostasis network control protein integrity in a cell. Under normal conditions or even mildly stressful conditions-such as at slightly increased temperatures-the proteostasis network is able to prevent proteins from misfolding. However, if a cell is placed under lots of stress this network may become overwhelmed and misfolded proteins can accumulate. To date, the proteostasis network has not been linked to the clearance of amyloids.

A protein called Sup35, which is found in budding yeast, can exist as two different prion forms. Previous studies have shown that briefly heating the yeast cells can 'cure' the so-called 'weak' form of the prion. The 'strong' prion form, however, was thought to be unaffected by elevated temperature. These previous studies had only tested yeast cells that had been dividing for a few generations; it was unknown if cells that had been dividing for longer might respond differently.

Klaips et al. found that a protein called Hsp104-which helps to fold proteins properly-can break down the amyloid aggregates. This protein is normally only present in small amounts, but heating causes the levels of Hsp104 to rise. Klaips et al. found that the extra Hsp104 protein associated with the aggregates and led to their disassembly. When Hsp104 was prevented from associating with the prions, the aggregates were not cured even if high levels of Hsp104 were present in the cell.

When budding yeast form new cells, a daughter cell 'buds' off from the mother cell. Klaips et al. found that mother cells exposed to heat retain most of the Hsp104 when the cell divides, and this retention allowed Hsp104 to accumulate to a level required for the breakdown of amyloid aggregates. Therefore, under normal conditions, amyloids persist because cell division keeps the amount of Hsp104 below this threshold.

Previously it had been thought that the physical characteristics of amyloids accounted for their resilience in the face of the cell mechanisms designed to counteract protein misfolding. However, Klaips et al. show that the balance of the different mechanisms involved in proteostasis can be manipulated to create environments where amyloids are either created and maintained or destroyed. Targeting these mechanisms could therefore present new treatment options for amyloidosis. DOI: 10.7554/eLife.04288.002

amyloid resolution, existing protein has not been demonstrated to transition from an amyloid to a nonamyloid form in any of the studies. Instead, two correlations have been observed where the reduced proteotoxicity has been linked to a change in amyloid state. Either amyloid accumulation is enhanced by chaperone overexpression (Douglas et al., 2009; Cushman-Nick et alo, 2013), or amyloid accumulation is reduced. In the few cases where the mechanism has been determined, the reduction in amyloid accumulation results from an inhibition of amyloid assembly by the overexpressed chaperone (Kobayashi et al., 2000; Schaffar et al., 2004; Tam et al., 2006; Shorter and Lindquist, 2008; Winkler et al., 2012). Thus, even the specific overexpression of individual chaperones is unable to extend the proteostasis upper boundary in vivo to resolve protein amyloids.

Although these targeted interventions have yet to succeed, studies conducted under conditions that reduce amyloid amplification indicate that amyloid clearance may not represent an insurmountable obstacle. For example, repressing expression of an amyloidogenic protein can reverse established toxicity and, at least in some cases, clear existing amyloid (Yamamoto et alo, 2000; Mallucci et alo, 2003; Lim et al., 2011). In addition, expression of a dominant-negative mutant also promotes disassembly of wild-type amyloid in vivo (DiSalvo et al., 2011). Together, these observations suggest that amyloid clearance mechanisms exist in vivo, and indeed amyloid resolution is biochemically feasible in vitro using purified chaperones such as yeast $\mathrm{Hsp104}$, alone or in combination with its co-chaperones Hsp40, Hsp70, and small heat shock proteins (Inoue et al., 2004; Shorter and Lindquist, 2004, 
Lo Bianco et al., 2008; Shorter and Lindquist, 2008). What limitations, then, restrict the ability of cells to expand proteostasis capacity to effectively resolve continuously expressed wild-type protein amyloids in vivo?

To identify cell-based limitations on proteostasis capacity, we focused on the mechanisms controlling persistence of the yeast prion $\left[\mathrm{PSI}^{+}\right]$, the alternative, self-templating, amyloid form of the Sup35 protein (Cox, 1965; Patino et al., 1996; Paushkin et al., 1996; Glover et al., 1997; King et al., 1997). In this study, we report that a transient thermal stress surprisingly leads to the complete disassembly of existing Sup35 amyloid. This process requires the accumulation of heat-induced non-prion protein aggregates in cells primarily at the later stages of the cell cycle. The engagement of Hsp104 with these substrates, and its inability to resolve them before cell division, leads to asymmetric retention of the chaperone in cells that experienced the thermal stress. As a result, Hsp104 accumulates to a level that is sufficient to resolve amyloid aggregates. Thus, the kinetics of substrate engagement by a POC factor and its partitioning during cell division impose cell-based limitations on proteostasis capacity.

\section{Results}

\section{Sup35 amyloid is resolubilized by Hsp104 following thermal stress}

Under normal growth conditions, $\left[P S I^{+}\right]$propagates faithfully (Cox, 1965; Derkatch et al., 1996). However, at elevated temperatures where the PQC capacity is increased, $\left[\mathrm{PSI}^{+}\right]$becomes destabilized in a Sup35 conformation-specific manner. For example, the more thermodynamically stable but less efficiently propagated $\left[\mathrm{PSI}^{+}\right]^{\text {Weak }}$ variant is quantitatively 'cured' (i.e. converted to the non-prion [psi'] state) at elevated temperature in comparison with $\left[\mathrm{PSI}^{+}\right]^{\text {Strong, }}$, whose propagation is unaltered under the same conditions (Cox et al., 1988; Derkatch et al., 1996; Jung et al., 2000; Tanaka et al., 2006; Newnam et al., 2011). This curing of $\left[\mathrm{PSI}^{+}\right]^{\text {Weak }}$ was linked to the inhibition of the molecular chaperone Hsp104 (Newnam et al., 2011), an observation that is seemingly counter to the idea that proteostasis capacity increases in response to stress (Morimoto, 2011). However, in this study, stationary phase cultures were only briefly diluted into fresh medium to re-establish exponential growth before exposure to elevated temperature (Newnam et al., 2011). Because stationary phase alters chaperone expression and blocks $\left[\mathrm{PSI}^{+}\right]$curing at elevated temperature (Gasch et al., 2000; Newnam et al., 2011), residual effects from the growth phase switch could alter the interaction between Sup35 aggregates and PQC factors. Therefore, we revisited the effects of elevated temperature on $\left[\mathrm{PSI}^{+}\right]$propagation, beginning with exponentially growing cultures.

To monitor transitions from the prion $\left[\mathrm{PSI}^{+}\right]$to the non-prion [psi $\left.{ }^{-}\right]$state, we used yeast strains encoding a premature termination codon (PTC) in the ADE1 gene. In $\left[\mathrm{PSI}^{+}\right]$strains, Sup35 is functionally compromised, leading to stop-codon read-through and the formation of white or pink colonies on rich medium, but in [psi ${ }^{-}$strains, termination is faithful at the PTC, leading to the formation of red colonies on rich medium (Chernoff et al., 1995). Transiently elevating the growth temperature from $30^{\circ} \mathrm{C}$ to $40^{\circ} \mathrm{C}$ had no effect on viability (Figure 1 -figure supplement $1 \mathrm{~A}$ ) or on [PSI+ $]^{\text {Strong }}$ propagation (Figure 1A) but induced [PSI+] $]^{\text {Weak }}$ curing (Figure 1A,B). Notably, both fully red and sectored colonies were observed, indicating that curing happened during both the thermal stress and subsequent recovery (Figure $1 \mathrm{~B}$ ). Thus, $\left[P S I^{+}\right]^{\text {Weak }}$ propagation is similarly sensitive to elevated temperature in exponentially growing cultures and in those that have recently exited stationary phase.

At the normal growth temperature, large Sup35 aggregates are fragmented into smaller complexes by Hsp104 (Chernoff et al., 1995; Eaglestone et al., 2000; Ness et al., 2002; Satpute-Krishnan et al., 2007; Kawai-Noma et al., 2009). In a culture that recently exited stationary phase, the size of SDS-resistant Sup35 aggregates increased, as assessed by semi-denaturing detergent agarose gel electrophoresis (SDD-AGE) (Kryndushkin et al., 2003), following incubation at $40^{\circ} \mathrm{C}$ and a $2 \mathrm{hr}$ recovery at $30^{\circ} \mathrm{C}$ (Figure 1-figure supplement 1B, left) (Newnam et al., 2011), consistent with an inhibition of fragmentation (Newnam et al., 2011). In contrast, SDS-resistant Sup35 aggregates were immediately reduced in size (Figure 1C, Figure 1-figure supplement 1B) and completely lost after recovery (Figure 1-figure supplement 1B, right) following identical treatment of an exponentially growing $\left[\mathrm{PSI}^{+}\right]^{\text {Weak }}$ strain, a progression suggesting the resolution of existing Sup35 aggregates. To test this possibility, we incubated a $\left[P S I^{+}\right]^{\text {Weak }}$ culture at $40^{\circ} \mathrm{C}$, returned the culture to $30^{\circ} \mathrm{C}$ in the presence of cycloheximide to repress new protein synthesis, and monitored the conversion of existing Sup35 from the amyloid $\left[\mathrm{PSI}^{+}\right.$] state (i.e. SDS-resistant) to the non-amyloid [psi ${ }^{-}$] state (i.e. SDS-sensitive) (Serio et al., 2000; Satpute-Krishnan and Serio, 2005). In a control culture at $30^{\circ} \mathrm{C}$, very little 


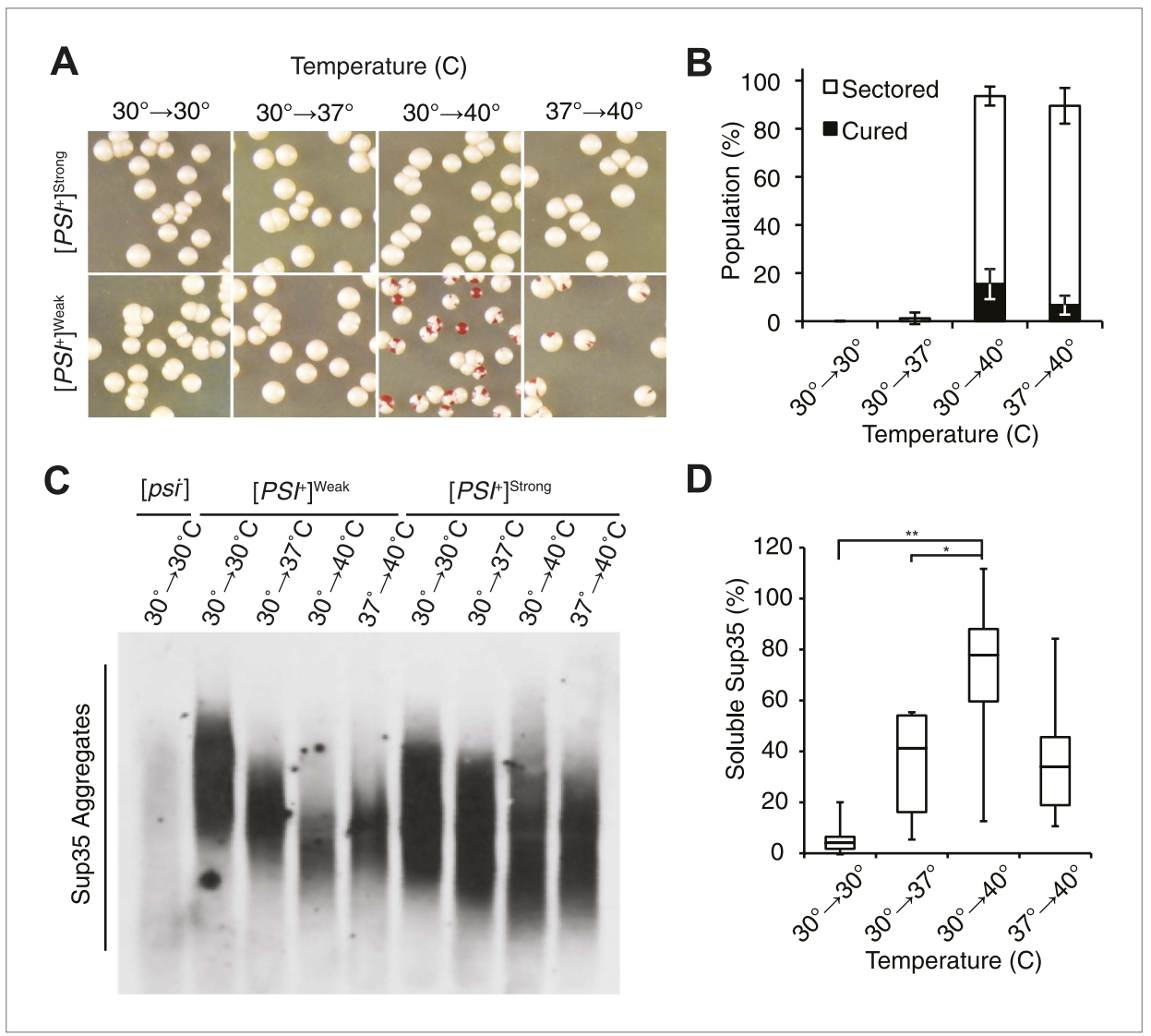

Figure 1. Thermal stress induces curing through resolution of Sup35 amyloid. (A) $\left[P S I^{+}\right]^{\text {Strong }}(\mathrm{SLL} 2606)$ and $\left[P S I^{+}\right]^{\text {Weak }}$ (SLL2600) cultures were incubated for $30 \mathrm{~min}$ at the indicated temperatures before plating on rich medium at $30^{\circ} \mathrm{C}$ to analyze curing by colony color phenotype, as described in the text. (B) Quantification of [PSI+] Weak (SLL2600) colony color phenotypes following treatment as described in (A). Colonies were scored as completely [psi'] (black), or sectored (partially [psi ${ }^{-}$, white). Data represent averages; error bars represent standard deviations; $\mathrm{n}=3$. (C) Semi-native lysates of [psi'] (SLL2119), [PSI+] Weak (SLL2600), and [PSI+] ${ }^{\text {Strong }}$ (SLL2606) cultures were analyzed by semi-denaturing detergent agarose gel electrophoresis (SDD-AGE) and immunoblotting for Sup35 after treatment as described in (A). (D) Sup35 released from amyoid aggregates in a [PSI+] $]^{\text {Weak }}$ strain (SLL2600) following treatment as described in $(\mathbf{A})$ and recovery at $30^{\circ} \mathrm{C}$ in the presence of cycloheximide was determined by treating lysates with $2 \%$ SDS at $53^{\circ} \mathrm{C}$, followed by SDS-PAGE and quantitative immunoblotting for Sup35. Lines represent medians; boxes represents upper and lower quartiles, and whiskers represent maximum and minimum; $n=5 ;{ }^{\star} p=0.02$, ${ }^{* *} \mathrm{p}=0.01$ by paired t-test.

DOI: 10.7554/eLife.04288.003

The following figure supplement is available for figure 1:

Figure supplement 1. Characterization of thermal stress effects.

DOI: 10.7554/eLife.04288.004

pre-existing Sup35 transitioned to an SDS-sensitive state despite the inhibition of new protein synthesis (Figure 1D), as expected (DiSalvo et al., 2011). However, following incubation at $40^{\circ} \mathrm{C}$, over $70 \%$ of SDS-resistant Sup35 became detergent sensitive during recovery at $30^{\circ} \mathrm{C}$ (Figure 1D), indicating disassembly of existing Sup35 amyloid. To determine if the prion curing resulting from this disassembly was mediated by $\mathrm{Hsp} 104$, we chemically inhibited this factor with guanidine $\mathrm{HCl}(\mathrm{GdnHCl})$ treatment or reduced its dosage by creating a heterozygous disruption in a diploid strain (Eaglestone et al., 1999; Jung and Masison, 2001; Grimminger et al., 2004; Kummer et al., 2013; Tariq et al., 2013; Zeymer et alo, 2013), and in both cases, $\left[P S I^{+}\right]^{\text {Weak }}$ curing was reduced by more than $50 \%$ relative to the wild-type untreated strain (Figure 2A,B). Thus, Hsp104 promotes the disassembly of existing Sup35 amyloid in a $\left[\mathrm{PSI}^{+}\right]^{\text {Weak }}$ strain following thermal stress.

At elevated temperature, we noted that the size of SDS-resistant Sup35 aggregates is reduced in a $\left[\mathrm{PSI}^{+}\right]^{\text {Strong }}$ strain (Figure $1 \mathrm{C}$ ), although curing does not occur (Figure 1A). Because $\left.[\mathrm{PSI}]^{+}\right]^{\text {Strong }}$ 


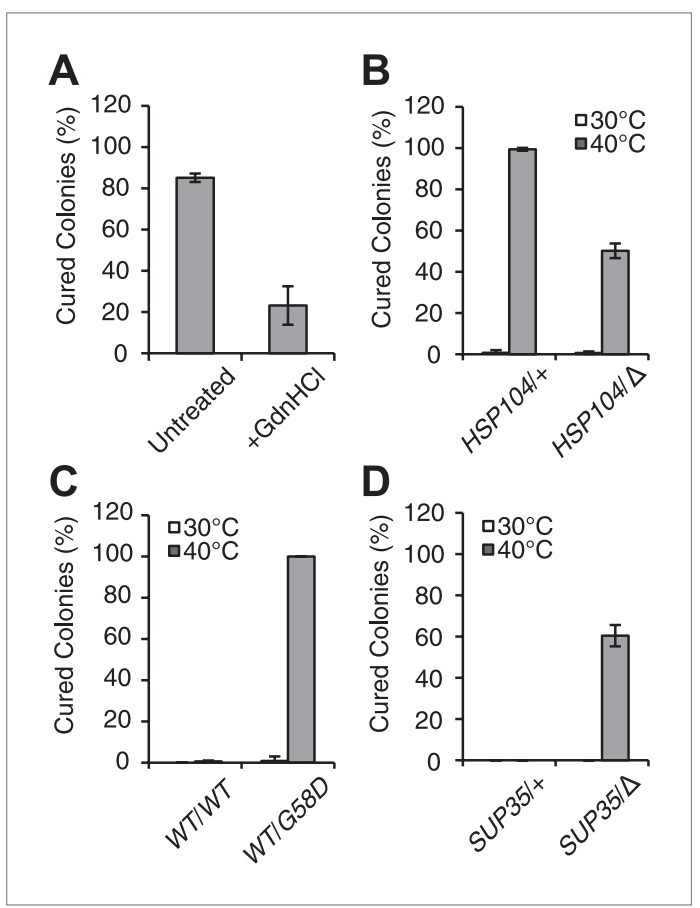

Figure 2. Curing is mediated by Hsp104 and depends upon propagation efficiency. (A) [PSI+] ${ }^{\text {Weak }}$ cultures (SLL2600) were incubated at $40^{\circ} \mathrm{C}$ for $30 \mathrm{~min}$ in the absence (untreated) or presence of guanidine $\mathrm{HCl}$ $(\mathrm{GdnHCl})$ and plated on YPD to quantify prion loss by colony color phenotype. Data represent means; error bars represent standard deviations; $n=3 ; p=0.0004$ by unpaired t-test. (B) A WT (HSP104/+; SY945) and a heterozygous disruption (HSP104/A; SY591) [PSI+ $]^{\text {Weak }}$ diploid strain were incubated at $40^{\circ} \mathrm{C}$ for $90 \mathrm{~min}$ and plated on YPD to quantify prion loss by colony color phenotype. Data represent means; error bars represent standard deviations; $n=3 ; p<0.0001$ by unpaired t-test. (C) $\left[\mathrm{PSI}^{+}\right]^{\text {Strong }}$ strains expressing an extra copy of either WT (SY1646) or G58D (SY1648) Sup35 were incubated at $40^{\circ} \mathrm{C}$ for $90 \mathrm{~min}$ and plated on YPD to quantify prion loss by colony color phenotype. Data represent means; error bars represent standard deviations; $\mathrm{n}=4 ; \mathrm{p}<0.0001$ by unpaired t-test. (D) A WT (SUP35/+; SLL3071) and a heterozygous disruption (SUP35/ $\Delta_{;}$SY957) diploid $\left[P S I^{+}\right]^{\text {Strong }}$ strain were incubated at $40^{\circ} \mathrm{C}$ for $90 \mathrm{~min}$ and plated on YPD to quantify prion loss by colony color phenotype. Data represent means; error bars represent standard deviations; $\mathrm{n}=3 ; \mathrm{p}<0.0001$ by unpaired t-test. DOI: 10.7554/eLife.04288.005 cated in Sup35 amyloid fragmentation (Cox, 1965; Chernoff et al., 1995; Song et alo, 2005; Higurashi et al., 2008; Tipton et al., 2008; Derdowski et al., 2010). By quantitative immunoblotting, neither Sup35 (Figure 3-figure supplement 1A) nor chaperone levels (Figure 3A, Figure 3-figure supplement $1 \mathrm{~B}$ ) correlated with curing efficiency (Figure 1A), indicating that $[\mathrm{PSI}+]^{\text {Weak }}$ curing could not be explained by simple changes in protein expression. Indeed, the specific overexpression of Hsp104 alone from a galactose-inducible promoter to levels that parallel those achieved during thermal stress (Figure $3 \mathrm{~A}$ and Figure 3-figure supplement $1 \mathrm{C}$ ) induces $\sim 40 \%\left[\mathrm{PSI} \mathrm{I}^{+}\right]_{\text {Weak }}$ curing (Figure 3-figure supplement 1D, $1.5 \mathrm{gen})$ in comparison with the $\sim 95 \%\left[P S I^{+}\right]^{\text {Weak }}$ curing induced by thermal stress

propagates more efficiently than $\left[P S I^{+}\right]^{\text {Weak }}$, the former may be protected from curing at elevated temperature if the rate of Sup35 assembly continued to outpace the rate of its disassembly, a scenario that should be reversed by reducing the efficiency of $\left[\mathrm{PSI}^{+}\right]^{\text {Strong }}$ propagation. To test this idea, we subjected $\left[P S I^{+}\right]^{\text {Strong }}$ diploid strains heterozygous for either a Sup35 mutant (G58D) or for a Sup35 disruption, which both reduce propagation efficiency (Derdowski et al., 2010; DiSalvo et al., 2011), to thermal stress. At $30^{\circ} \mathrm{C},\left[\mathrm{PSI}^{+}\right]$ propagation is stable in both of these strains (Figure $2 \mathrm{C}, \mathrm{D}$ ); however at $40^{\circ} \mathrm{C}$, both were now efficiently cured (e.g. $~ 100 \%$ for WT/G58D, $60 \%$ for SUP35/D) (Figure 2C,D). These observations not only provide additional support for Sup35 amyloid disassembly as the mechanism of prion curing in response to thermal stress but also reveal that the inability of chaperones to resolve amyloid in vivo results from both the physical characteristics of these aggregates and cell-based limitations, which are bypassed in the distinct proteostasis niche created at elevated temperature.

\section{The asymmetric retention of Hsp104 is required for curing}

Elevated temperature induces protein misfolding, and the cell responds to this stress by elevating the expression of PQC factors (Morimoto, 2011). To deconvolute the contributions of each of these events to $\left[P S I^{+}\right]^{\text {Weak }}$ curing, we took advantage of the fact that we could modulate the efficiency of curing with variations in temperature. For example, while exposure to $40^{\circ} \mathrm{C}$ induced quantitative $\left[P S I^{+}\right]^{\text {Weak }}$ curing, pretreatment at $37^{\circ} \mathrm{C}$ prior to exposure to $40^{\circ} \mathrm{C}$ slightly reduced curing (Figure $1 A, B$, compare proportion of fully cured colonies), and incubation at $37^{\circ} \mathrm{C}$ did not induce curing at all (Figure $1 A, B$ ). This failure to destabilize $\left[P S I^{+}\right]^{\text {Weak }}$ at $37^{\circ} \mathrm{C}$ corresponded to an increase in aggregate size (Figure $1 C$ ) and a decrease in Sup35 solubilization (Figure 1D) relative to growth at $40^{\circ} \mathrm{C}$ alone, indicating a temperaturedependent modulation of amyloid resolution.

To determine the molecular basis of these differences in curing efficiency, we first monitored the levels of Sup35, Hsp104, Ssa1/2 (Hsp70), and Sis1 (Hsp40) proteins, which have all been impli- 


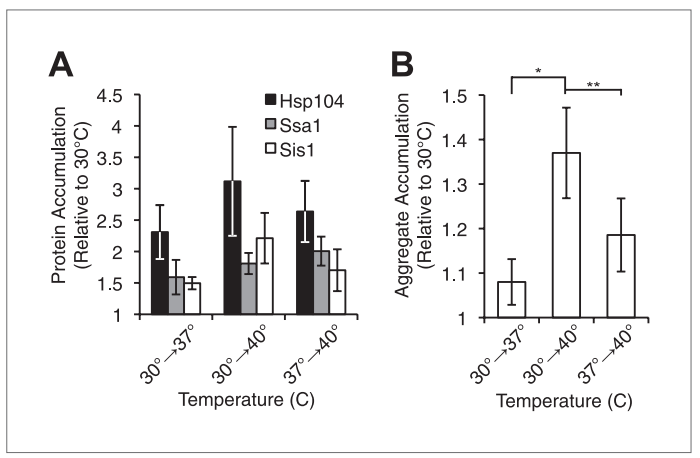

Figure 3. Heat-induced aggregate accumulation but not chaperone levels correlate with temperature. (A) A $\left[\mathrm{PSI}^{+}\right]^{\text {Weak }}$ strain (SLL2600) was incubated at $30^{\circ} \mathrm{C}$, $37^{\circ} \mathrm{C}, 40^{\circ} \mathrm{C}$, or $37^{\circ} \mathrm{C}$ before $40^{\circ} \mathrm{C}$ for $30 \mathrm{~min}$, and lysates were prepared and analyzed by SDS-PAGE and quantitative immunoblotting for Hsp104 (black), Ssa1 (gray), and Sis1 (white). Data represent means; error bars represent standard deviations; $n \geq 3$. (B) Aggregates from lysates of a $\left[\mathrm{PSI}^{+}\right]^{\text {Weak }}$ strain (SLL2600) following treatment as described in (A) were prepared and analyzed by differential centrifugation and Bradford assay. Data represent means; error bars represent standard error; $n=6 ;{ }^{*} p=0.0014,{ }^{* *} p=0.0052$ by paired t-test.

DOI: 10.7554/eLife.04288.006

The following figure supplement is available for figure 3:

Figure supplement 1. Effects of thermal stress and Hsp104 on protein accumulation.

DOI: 10.7554/eLife.04288.007
(Figure 1B) (DiSalvo et al., 2011, Wegrzyn et al., 2001). Moreover, Hsp104 overexpression alone leads to an increase in the size of SDS-resistant Sup35 aggregates isolated from a $\left[\mathrm{PSI}^{+}\right]^{\text {Weak }}$ strain (Kryndushkin et al., 2003), as previously reported for $\left[\mathrm{PSI}^{+}\right]^{\text {Strong }}$ (Figure 3-figure supplement 1E) (Kryndushkin et al., 2003), but this outcome is in obvious contrast to the disassembly of Sup35 amyloid that we observe upon thermal stress (Figure 1C,D). Thus, thermal stress and chaperone overexpression induce distinct changes in prion propagation.

We next assessed the accumulation of misfolded proteins following shifts in temperature to determine if this event correlated with $\left[\mathrm{PSI}^{+}\right]^{\text {Weak }}$ curing efficiency. By differential centrifugation, protein aggregates accumulated independent of prion status at all elevated temperatures (Figure 3B, Figure 3-figure supplement 1F), but in contrast to chaperone expression (Figure 3A, Figure 3-figure supplement 1B), the severity of this accumulation was impacted by growth temperature. At $37^{\circ} \mathrm{C}$, protein aggregation increased by less than $10 \%$ in comparison with a culture maintained at $30^{\circ} \mathrm{C}$ (Figure 3B, column 1), but in cultures treated at $37^{\circ} \mathrm{C}$ followed by $40^{\circ} \mathrm{C}$ or directly at $40^{\circ} \mathrm{C}$, this level rose to $\sim 20 \%$ or $\sim 40 \%$, respectively (Figure $3 B$, columns 3 and 2). Thus, the accumulation of protein aggregates (Figure 3B) correlates directly with curing efficiency at the various temperatures (Figure 1A).

We noted, however, that this correlation was not observed for a $\left[\mathrm{PSI}^{+}\right]^{\text {Weak }}$ culture treated with $\mathrm{GdnHCl}$ during a $40^{\circ} \mathrm{C}$ incubation, which strongly reduced curing efficiency (Figure 2A) but did not reduce the accumulation of protein aggregates (Figure 3-figure supplement 1G). Nevertheless, numerous studies have reported the localization of chaperones to cytoplasmic quality control foci upon exposure to proteotoxic stresses (Aguilaniu et al., 2003; Erjavec et al., 2007; Kaganovich et al., 2008; Specht et al., 2011; Wolfe et al., 2013), and GdnHCl blocks the association of Hsp104 with at least one substrate (Winkler et al., 2012). To determine if Hsp104 localization to heat-induced aggregates rather than their accumulation per se determined prion-curing efficiency, we replaced endogenous HSP104 with an HSP104-GFP fusion, which supports [PSI'] propagation (Figure 4figure supplement $1 \mathrm{~A}$ ). At $40^{\circ} \mathrm{C}$, this strain exhibited time-dependent $\left[P S I^{+}\right]^{\text {Weak }}$ curing (Figure 4figure supplement $1 \mathrm{~B}$ ) and accumulated protein aggregates (Figure 4-figure supplement 1C) and Hsp104-GFP to wild-type levels, albeit with slightly delayed kinetics (Figure 4-figure supplement 1D). At elevated temperatures, we observed an increase Hsp104-interacting proteins as assessed by co-immunocapture (Figure 4A) and the localization of Hsp104-GFP to cytoplasmic foci (Figure 4B,C), which also contain the model substrate firefly luciferase-mCherry (Figure 4-figure supplement 1E). The amount of co-immunocaptured proteins (Figure $4 \mathrm{~A}\left[2.5\right.$-fold increase at $37^{\circ} \mathrm{C}$ and 4.2 -fold increase at $40^{\circ} \mathrm{C}$ relative to $30^{\circ} \mathrm{C}$ ) and the number and intensity of Hsp104-GFP fluorescent foci (Figure 4C) corresponded to both the accumulation of heat-induced protein aggregates (Figure $3 B$ ) and the efficiency of curing (Figure 1A). Notably, the Hsp104-GFP fluorescence pattern was unaltered in a nonprion [psi ${ }^{-}$] strain (Figure 4B), indicating that Hsp104-GFP was engaged with non-prion substrates. Treatment of a $\left[\mathrm{PSI}^{+}\right]^{\text {Weak }}$ culture with $\mathrm{GdnHCl}$ during an incubation at $40^{\circ} \mathrm{C}$, which strongly reduces Hsp104-GFP association with heat-induced interacting proteins (Figure 4A [1.7-fold decrease relative to $40^{\circ} \mathrm{C}$ in the absence of $\mathrm{GdnHCl}$ ) and localization to cytoplasmic foci (Figure 4-figure supplement 1F), also reduces the efficiency of curing (Figure 2A, Figure 4-figure supplement 1G). Thus, 


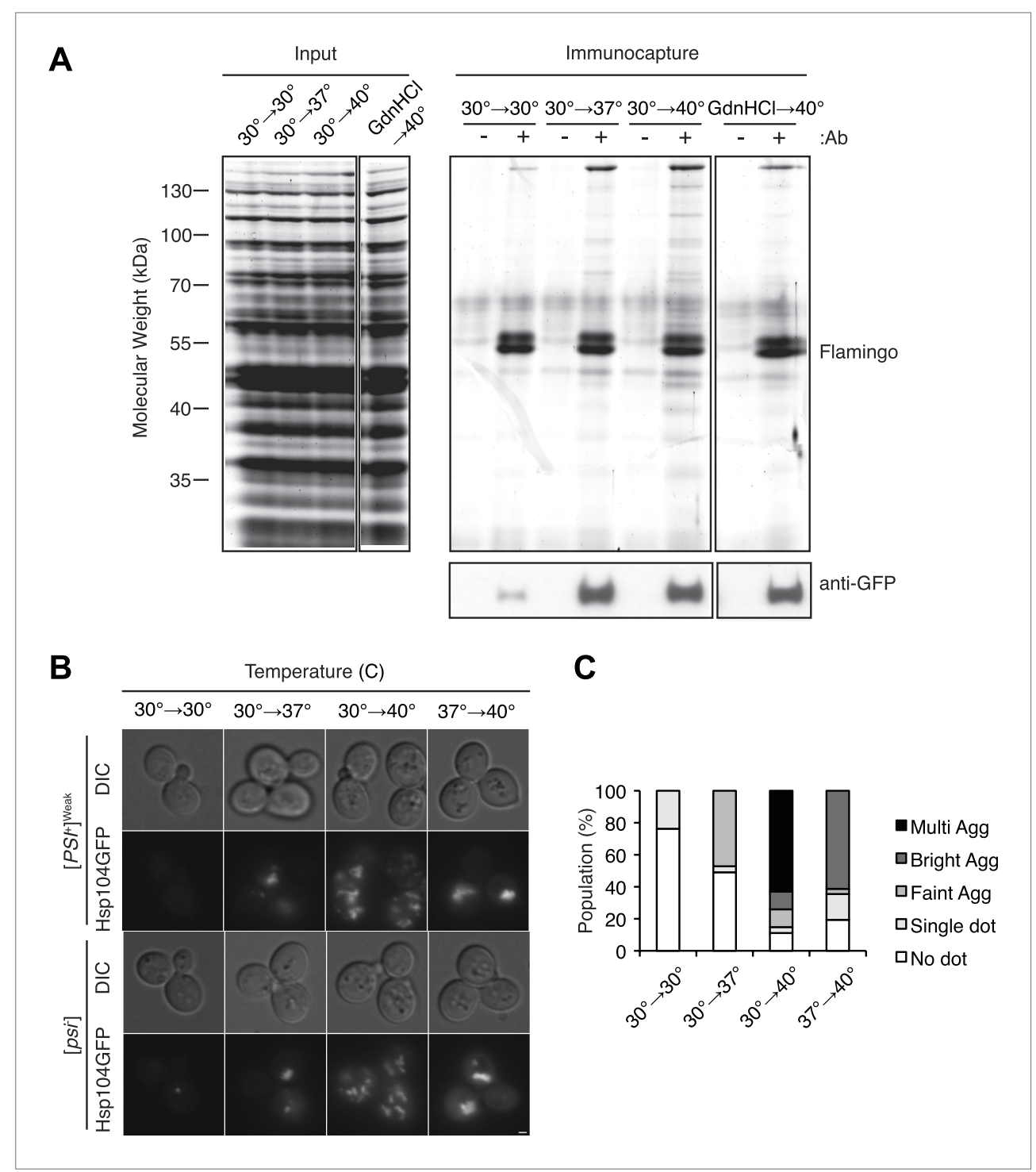

Figure 4. Hsp104 engages heat-induced substrates upon thermal stress. (A) A [PSI+ $]^{\text {Weak }}$ strain with a GFP-tagged endogenous Hsp104 (SY2126) was incubated at $30^{\circ} \mathrm{C}, 37^{\circ} \mathrm{C}, 40^{\circ} \mathrm{C}$, or $40^{\circ} \mathrm{C}$ with $\mathrm{GdnHCl}$ for 30 min, and immunocapture in the presence (+) or absence (-) of anti-GFP antibodies (Ab) was performed on native lysates. Proteins were analyzed by SDS-PAGE and general protein staining (Flamingo, top), or immunoblotting for GFP (bottom). (B) $\left[\mathrm{PSI}^{+}\right]^{\text {Weak }}(\mathrm{SY} 2126)$ or $\left[\mathrm{psi}^{-}\right]$(SY2125) HSP104GFP strains were incubated at $30^{\circ} \mathrm{C}, 37^{\circ} \mathrm{C}, 40^{\circ} \mathrm{C}$, or $37^{\circ} \mathrm{C}$ before $40^{\circ} \mathrm{C}$ for $90 \mathrm{~min}$, and the pattern of Hsp104-GFP fluorescence was examined by microscopy. Scale bar $=1 \mu \mathrm{m}$. (C) Quantification of Hsp104-GFP fluorescence pattern in [PSI+] Weak (SY2126) cells, treated as described in (B): no localization (white); single dot (light gray); faint aggregate (medium gray); bright aggregate (dark gray); multiple bright aggregates (black); $\mathrm{n}>25$.

DOI: 10.7554/eLife.04288.008

The following figure supplement is available for figure 4:

Figure supplement 1. Characterization of HSP104GFP strain.

DOI: 10.7554/eLife.04288.009

the specific engagement of Hsp104 with heat-induced aggregates, rather than simply their presence, correlates with curing at elevated temperature.

How does this chaperone engagement with heat-induced aggregates lead to the resolution of Sup35 amyloid? One possibility is that the asymmetric localization of Hsp104, resulting from its engagement with heat-induced protein aggregates (Erjavec et al., 2007), increases its accumulation in a subpopulation of cells beyond that which can be achieved by its transcriptional up-regulation. To 
test this possibility, we first monitored the partitioning of Hsp104-GFP during cell division following incubation at various temperatures using microfluidics and fluorescence microscopy. Starting with budded cells, mother cells accumulated $\sim 60 \%$ of Hsp104-GFP following the completion of cell division at $30^{\circ} \mathrm{C}$ (Figure $5 \mathrm{~A}$, gray), which is comparable to the accumulation of untagged GFP expressed from the same promoter (Figure 5-figure supplement 1A) and thus likely reflects the volume differences between mother and daughter cells. This baseline asymmetry progressively increased as the temperature was increased to $37^{\circ} \mathrm{C}\left(\sim 65 \%\right.$ retention), $37^{\circ} \mathrm{C}$ followed by $40^{\circ} \mathrm{C}(\sim 73 \%$ retention), and finally $40^{\circ} \mathrm{C}(\sim 75 \%$ retention; Figure $5 \mathrm{~A}$, gray). Notably, both Ssa1-GFP and Sis1-GFP fusions also localized to cytoplasmic, and, in the case of Sis1, nuclear foci (Figure 5-figure supplement 1B,C), but neither was asymmetrically retained following incubation at $40^{\circ} \mathrm{C}$ (Figure 5-figure supplement 1D,E), although their levels were elevated relative to $30^{\circ} \mathrm{C}$ (Table 1) due to their enhanced expression (Figure 3A). Thus, curing efficiency (Figure 1A,B) correlates directly with the asymmetric retention of Hsp104 in cells at elevated temperature.

To determine if this correlation was a requirement, we next disrupted the asymmetric retention of Hsp104 and determined its effects on curing. Disruption of the formin BNI1 (Kohno et al., 1996) did not alter Hsp104 expression levels or the accumulation of protein aggregates at $30^{\circ} \mathrm{C}$ and $40^{\circ} \mathrm{C}$ relative to a wild-type strain, (Figure 5-figure supplement $1 F, G$ ) but, Hsp104 asymmetric retention was reduced (Figure 5B, green), as expected (Liu et al., 2010). Strikingly, curing was dramatically suppressed from $\sim 80 \%$ for a wild-type strain to $\sim 10 \%$ in the $\Delta$ bni1 strain (Figure $5 C$ ). Likewise, $\mathrm{GdnHCl}$ treatment before thermal stress, which blocked both Hsp104 engagement with heat-induced aggregates (Figure 4-figure supplement 1F) and curing at elevated temperature (Figure 2A, Figure 4-figure supplement 1G), also reduced Hsp104-GFP asymmetric retention following exposure to $40^{\circ} \mathrm{C}$ (Figure 5D). Thus, the asymmetric retention of $\mathrm{Hsp} 104$ is required for curing.

Our single-cell analyses of Hsp104-GFP partitioning indicated that a relatively minor change in chaperone retention from $65 \%$ to $75 \%$, which corresponded to a 2.2 -fold increase in accumulation based on fluorescence intensity (compare $37^{\circ} \mathrm{C}-40^{\circ} \mathrm{C}$, Table 1, Figure $5 \mathrm{~A}$ ), correlated with a quantitative switch from prion stability to curing (Figure $1 A, B$ ), suggesting the existence of a biological threshold in this range. To determine directly if cells accumulating Hsp104-GFP corresponded to those cured of $\left[P \mathrm{PI}^{+}\right]^{\text {Weak }}$, we incubated a $\left.[\mathrm{PSI}]^{+}\right]^{\text {Weak }}$ culture at $40^{\circ} \mathrm{C}$ and then isolated single unbudded cells on rich solid medium at $30^{\circ} \mathrm{C}$. Following budding and cell division, mother and daughter cells were separated by micromanipulation and grown into colonies, which were then dispersed on rich solid medium to quantify prion retention. Mother cells, which experienced the elevated temperature and accumulated Hsp104 (Figure 5A), were more likely to be cured than their daughters (Figure 5E, note most data points fall below the diagonal), as predicted by our hypothesis. To more quantitatively correlate Hsp104-GFP accumulation with curing efficiency, we analyzed the distribution of Hsp104-GFP in a population of cells by flow cytometry. At $30^{\circ} \mathrm{C}$, Hsp104-GFP fluorescence was distributed normally in the population (Figure $5 \mathbf{F}$, dotted). Following incubation at $40^{\circ} \mathrm{C}$, Hsp104-GFP fluorescence intensity in the population increased and its distribution was heterogeneous (Figure $\mathbf{5 F}$, solid). When these subpopulations were separated by FACS and analyzed for colony-based phenotype, the efficiency of curing correlated directly with the accumulation of Hsp104-GFP (Figure 5F, G). Together, these observations indicate that cells exposed to elevated temperature accumulate heat-induced protein aggregates, asymmetrically retain Hsp104 in a manner that is proportional to these substrates, and ultimately cure $\left[\mathrm{PSI}{ }^{+}\right]^{\text {Weak }}$.

But, is Hsp104 enzymatic activity required for this curing, or is its asymmetric localization alone sufficient? As noted above, when cells are treated with $\mathrm{GdnHCl}$ before thermal stress, $\mathrm{Hsp} 104$ localization to cytoplasmic foci and asymmetric retention are both reduced (Figure 5D, Figure 4figure supplement 1F). However, we reasoned the Hsp104 association with its substrates would be dynamic and modulated by its ATPase cycle. Indeed, blocking the ATPase activity of Hsp104 after thermal stress with a 90-min treatment with $\mathrm{GdnHCl}$ failed to reduce Hsp104-GFP localization to cytoplasmic foci (Figure 4-figure supplement 1F) or its asymmetric retention (Figure 5D), presumably because the chaperone bound to heat-induced substrates but was unable to release them once inhibited with $\mathrm{GdnHCl}$. Despite the asymmetric localization of Hsp104-GFP under these conditions, $\left[\mathrm{PSI}^{+}\right]^{\text {Weak }}$ curing was reduced by nearly 50\% (Figure 4-figure supplement $1 \mathrm{G}$ ). Thus, both $\mathrm{Hsp} 104$ asymmetric localization and activity are required to induce $\left[P S I^{+}\right]^{\text {Weak }}$ curing following thermal stress. 


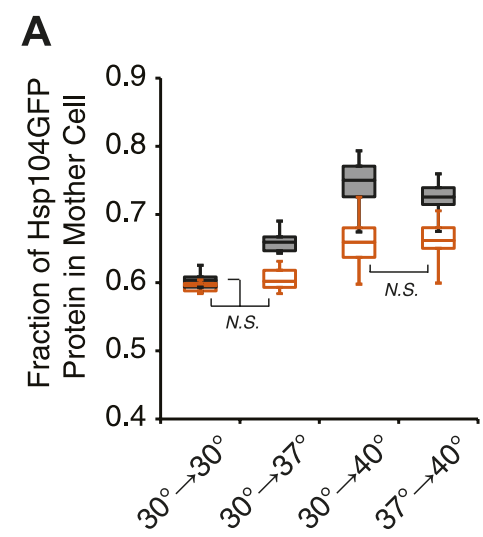

D
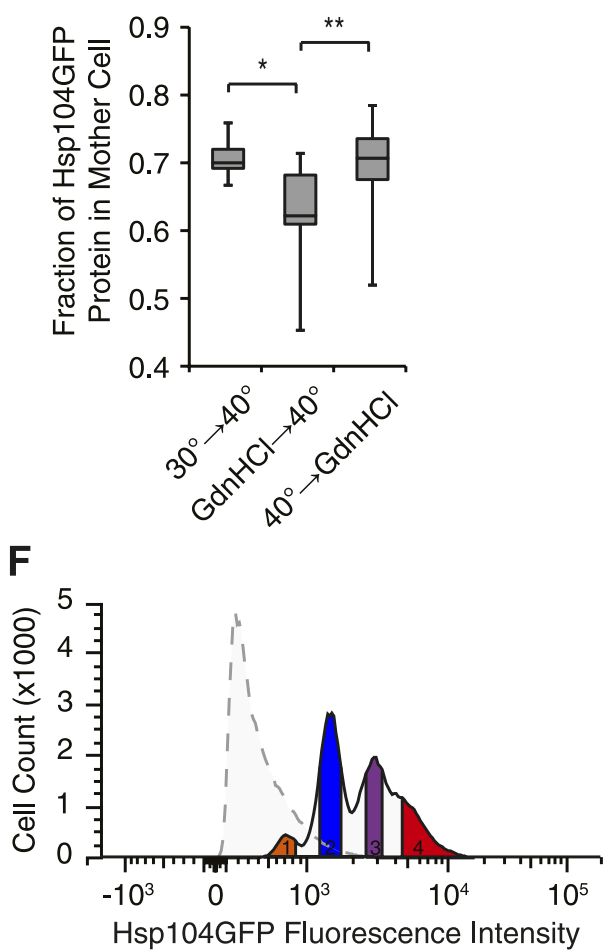

B

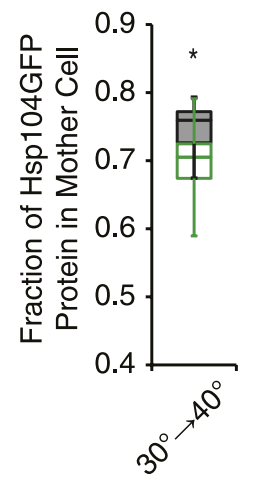

C

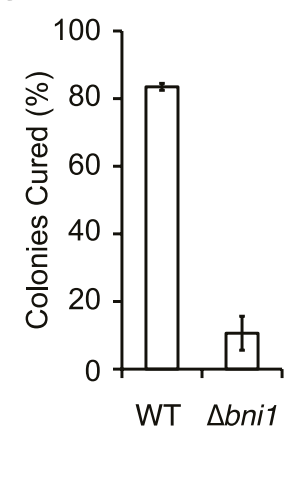

E

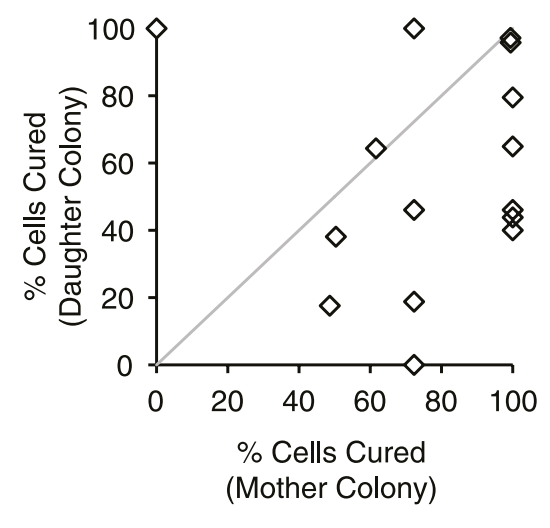

G

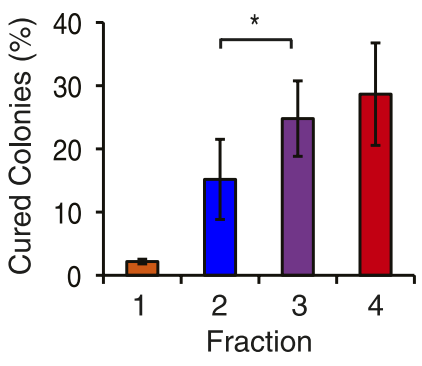

Figure 5. Curing results from the asymmetric localization of $\mathrm{Hsp} 104$ following thermal stress. (A) A [PSI+] $]^{\text {Weak }}$ HSP104GFP culture (SY2126) was imaged over time in a microfluidics chamber at $30^{\circ} \mathrm{C}$ after a 30 min incubation at $30^{\circ} \mathrm{C}, 37^{\circ} \mathrm{C}, 40^{\circ} \mathrm{C}$, or $37^{\circ} \mathrm{C}$ before $40^{\circ} \mathrm{C}$. Fluorescence intensity in daughter and mother cells was quantified at the first cell division in cells that were budded (gray) or unbudded (orange) after thermal stress. Lines represent medians; boxes represent upper and lower quartiles, and whiskers represent maximum and minimum. All pairwise comparisons are significantly distinct, with a $p<0.015$, except where indicated (N.S.), by unpaired t-test; $n \geq 10$.

(B) A [PSI+] Weak HSP104GFP WT (SY2126, gray) or BNI1 deletion strain (Abni1) (SY2486, green) was imaged over time in a microfluidics chamber at $30^{\circ} \mathrm{C}$ after a $30 \mathrm{~min}$ incubation at $40^{\circ} \mathrm{C}$. Fluorescence intensity in daughter and mother cells was quantified at the first cell division. Lines represent medians; boxes represent upper and lower quartiles; and whiskers represent maximum and minimum; $n \geq 14 ; \mathrm{p}=0.0075$ by unpaired t-test. (C) $\left[P S I^{+}\right]^{\text {Weak }}$ WT (SLL2600) or $\Delta$ bni1 strains (SY1888), treated as described in (B), were plated on YPD to analyze curing by colony color phenotype. Data represent means; error bars represent standard deviations; $n=3 ; p<0.0001$ by unpaired t-test. (D) A [PSI+] Weak HSP104GFP strain (SY2126) was imaged over time in a microfluidics chamber at $30^{\circ} \mathrm{C}$ after a $30 \mathrm{~min}$ incubation at $40^{\circ} \mathrm{C}$ and with $\mathrm{GdnHCl}$ added before or after the $40^{\circ} \mathrm{C}$ incubation. Fluorescence intensity in daughter and mother cells was quantified at the first cell division. Lines represent medians; boxes represent upper and lower quartiles; and whiskers represent maximum and minimum; $n>11 ;{ }^{*} p=0.0003,{ }^{* *} p=0.0026$ by unpaired t-test. Figure 5. Continued on next page 
Figure 5. Continued

(E) A [PSI+] $]^{\text {Weak }}$ strain (SLL2600) was incubated at $40^{\circ} \mathrm{C}$ for $30 \mathrm{~min}$ and plated on rich medium. Mother and daughter pairs were separated by micromanipulation and allowed to form colonies, which were then dispersed to YPD for analysis of curing by colony color phenotype. $n=15$. (F) A [PSI+ $]^{\text {Weak }}$ HSP104GFP culture (SY2126) was incubated at $30^{\circ} \mathrm{C}$ (dotted) or at $40^{\circ} \mathrm{C}$ for $30 \mathrm{~min}$ and allowed to recover for $30 \mathrm{~min}$ at $30^{\circ} \mathrm{C}$ (solid) before analysis of GFP fluorescence intensity by flow cytometry. Based on these intensities, cells were sorted into four fractions (orange, blue, purple, red) by FACS. (G) Cells collected in (F) were plated on YPD to analyze curing by colony color phenotype. Data represent means; error bars represent standard deviations; $n=2 ;{ }^{*} \mathrm{p}=0.02$ by paired t-test. DOI: 10.7554/eLife.04288.010

The following figure supplement is available for figure 5 :

Figure supplement 1. Characterization of chaperone asymmetric retention following thermal stress. DOI: 10.7554/eLife.04288.011

\section{Cell-cycle stage and substrate-chaperone dynamics impact amyloid resolution}

The distribution of Hsp104-GFP in a population of [PSI+ $]^{\text {Weak }}$ cells that had been exposed to $40^{\circ} \mathrm{C}$ was very complex in contrast to the normal distribution of $\mathrm{Hsp} 104-\mathrm{GFP}$ at $30^{\circ} \mathrm{C}$ (Figure $5 \mathrm{~F}$ ), suggesting that subpopulations of cells were differentially retaining the chaperone. One source of heterogeneity in the population was cell-cycle stage, as our experiments used asynchronous cultures (Figure 6A). To determine if cell-cycle stage at the time of thermal stress impacted Hsp104 partitioning and explained this heterogeneity, we arrested cells in G1 with a-factor or at the G2/M transition with nocodazole (Amon, 2002), exposed these cultures to $40^{\circ} \mathrm{C}$ incubation, and analyzed them by flow cytometry. Treatment with $\alpha$-factor (Figure 6B) and nocodazole (Figure 6C) efficiently synchronized cultures at the non-budded or large-budded stages, respectively, and did not alter Hsp104 protein levels or localization relative to the asynchronous culture at $30^{\circ} \mathrm{C}$ (Figure 6 -figure supplement $1 \mathrm{~A}, \mathrm{~B}$ ). At $40^{\circ} \mathrm{C}$, Hsp104-GFP protein levels increased to similar extents in the asynchronous and arrested cultures (Figure 6-figure supplement 1A), and its localization to cytoplasmic foci was similar in all cases (Figure 6-figure supplement 1B). By flow cytometry, the distribution of Hsp104-GFP in the a-factor arrested culture remained normal (Figure 6D), but in the nocodazole-arrested culture, this distribution became bimodal (Figure 6E), indicating that Hsp104-GFP asymmetry is established immediately, even before cell division.

We next assessed the impact of cell-cycle stage on $\left[P S I^{+}\right]^{\text {Weak }}$ curing at elevated temperature. Arrest, without exposure to elevated temperature, did not induce curing (Figure 6F, G). In a-factor arrested cells, exposure to $40^{\circ} \mathrm{C}$ at release inefficiently cured $\left[\mathrm{PSI}^{+}\right]^{\text {Weak }}(\sim 15 \%$; Figure $6 \mathrm{~F})$, but in nocodazolearrested cells, curing was nearly quantitative ( 90\%; Figure 6G) consistent with the asymmetric localization of Hsp104-GFP in the latter but not the former case (Figure 6D,E). These observations suggest that cells at the end of the cell cycle are more sensitive to curing at elevated temperature than those at the beginning of the cell cycle. To test this idea, we released cultures from arrest and, after 30 min of growth at $30^{\circ} \mathrm{C}$, exposed them to $40^{\circ} \mathrm{C}$. For the culture originally arrested with a-factor, sensitivity to curing at elevated temperature increased (Figure $6 F$ ) as cells progressed into the late stages of the

Table 1. Relative fluorescence intensity in mother cells

\begin{tabular}{lccc} 
Treatment $\left({ }^{\circ} \mathrm{C}\right)$ & Hsp104 (Relative to $30^{\circ} \mathrm{C}$ ) & Ssa1 (Relative to $30^{\circ} \mathrm{C}$ ) & Sis1 (Relative to $30^{\circ} \mathrm{C}$ ) \\
\hline $30^{\circ} \rightarrow 30^{\circ}$ & $1 \pm 0.1(24)$ & $1 \pm 0.2(29)$ & $1 \pm 0.1(18)$ \\
\hline $30^{\circ} \rightarrow 37^{\circ}$ & $1.6 \pm 0.2(11)$ & & \\
\hline $30^{\circ} \rightarrow 40^{\circ}$ & $3.5 \pm 0.6(52)$ & $2.7 \pm 0.5(18)$ & $1.5 \pm 0.1(7)$ \\
\hline $37^{\circ} \rightarrow 40^{\circ}$ & $3.4 \pm 0.4(46)$ & & \\
\hline
\end{tabular}

$[$ [PSI+] Weak HSP104GFP(SY2126), SSA1GFP (SY2658), or SIS1GFP (SY2447) cultures were treated at indicated temperatures and were imaged over time at $30^{\circ} \mathrm{C}$ using microfluidics and fluorescence microscopy. Average fluorescence intensity in mother cells with indicated standard deviations ( \pm ), which originated from budded cells at the time of thermal stress, was measured at the first cell division. Number of cells analyzed is indicated in parentheses. $p$ values are $<0.001$ for all comparisons to $30^{\circ} \mathrm{C}$ treatment.

DOI: 10.7554/eLife.04288.012 


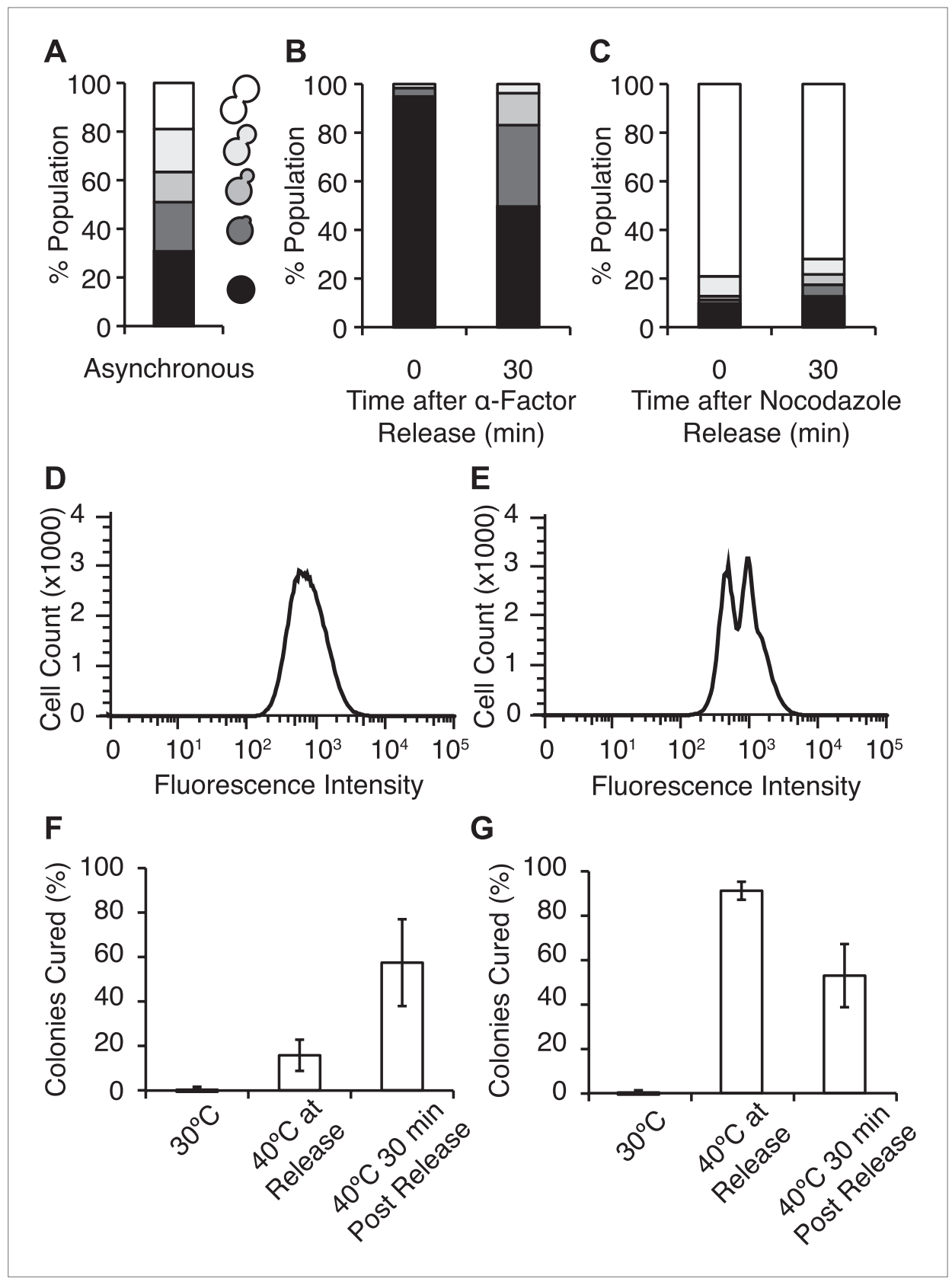

Figure 6. Efficient curing occurs in late cell-cycle staged cells following thermal stress. (A) Single cells from an asynchronous WT [PSI+] ${ }^{\text {Weak }}$ culture (SLL2600) were scored for morphology following brightfield imaging by microscopy: unbudded (black), tiny bud (dark gray), small bud (gray), medium bud (light gray), large bud (white). $\mathrm{n}=153$. (B) $\alpha$-factor-arrested cultures were analyzed as in (A) over time after release. $n \geq 250$. (C) Nocodazole-arrested cultures were analyzed as in (A) over time after release. $n \geq 175$. (D) A [PSI+] Weak HSP104GFP strain (SY2126) released from a-factor arrest was incubated at $40^{\circ} \mathrm{C}$ (solid black lines) for 30 min before analysis by flow cytometry. 100,000 cells were analyzed per sample. (E) A [PSI+'] Weak HSP104GFP strain (SY2126) released from nocodazole arrest was incubated at at $40^{\circ} \mathrm{C}$ (black lines) for 30 min before analysis by flow cytometry. 100,000 cells were analyzed per sample. (F) $\alpha$-factor-arrested cultures (SLL2600) were incubated at $40^{\circ} \mathrm{C}$ for $30 \mathrm{~min}$ immediately or $30 \mathrm{~min}$ after release, and curing was quantified by colony color phenotype after plating on YPD at $30^{\circ} \mathrm{C}$. Data represent means; error bars represent standard deviations; $\mathrm{n}=3 ; \mathrm{p}=0.0255$ by unpaired t-test. (G) Nocodazole-arrested cultures (SLL2600) were incubated at $40^{\circ} \mathrm{C}$ for $30 \mathrm{~min}$ immediately or $30 \mathrm{~min}$ after release, and curing was quantified colony color phenotype after Figure 6. Continued on next page 
Figure 6. Continued

plating on $\mathrm{YPD}$ at $30^{\circ} \mathrm{C}$. Data represent means; error bars represent standard deviations; $n=3 ; p=0.0263$ by unpaired t-test.

DOI: 10.7554/eLife.04288.013

The following figure supplement is available for figure 6:

Figure supplement 1. Characterization of chaperone accumulation and engagement in arrested cultures. DOI: 10.7554/eLife.04288.014

cell cycle (Figure 6B), and for the culture originally arrested with nocodazole, this sensitivity declined (Figure 6G) with cell-cycle progression (Figure 6C). Thus, curing occurs most efficiently when cells at a late stage of the cell cycle are exposed to elevated temperature.

Our earlier experiments linked curing to the asymmetric retention of Hsp104 at elevated temperature (Figure 5). To determine if cell-cycle stage impacts this asymmetry, we analyzed Hsp104-GFP distribution in mother-daughter pairs resulting from the growth and division of unbudded cells isolated from asynchronous cultures that were exposed to elevated temperatures. In comparison with budded cells, Hsp104-GFP retention was significantly reduced at all temperatures when unbudded cells were exposed to elevated temperature, but the magnitude of the effect was most severe for conditions that induced curing $\left(30^{\circ} \mathrm{C} \rightarrow 40^{\circ} \mathrm{C}\right.$ and $37^{\circ} \mathrm{C} \rightarrow 40^{\circ} \mathrm{C}$; Figure $5 \mathrm{~A}$, orange), indicating a cellcycle stage dependence on Hsp104-GFP retention at elevated temperature.

Because cell-cycle stage did not obviously alter the engagement of Hsp104-GFP with protein aggregates accumulating at elevated temperature (Figure 6-figure supplement 1B), the more efficient partitioning of Hsp104-GFP and the reduced curing in unbudded cells could reflect the resolution of heat-induced protein aggregates and thereby the release of Hsp104-GFP during the extended time before cell division in comparison with budded cells. Indeed, nearly $100 \%$ of cells contained Hsp104-GFP foci immediately after thermal stress (Figure $7 A$ ) but only $\sim 80 \%$ still contained foci when cell division re-initiated $\sim 150 \mathrm{~min}$ after incubation at $40^{\circ} \mathrm{C}$ (Figure $7 \mathrm{~A}$ ). Thus, the relative timing of substrate release and cell division could contribute to Hsp104 asymmetric retention and thereby curing. Consistent with this idea, 60\% of unbudded cells, which are inefficiently cured (Figure 6F), resolved Hsp104-GFP foci prior to cell division (Figure 7B [165-210 min], Figure 7C), allowing the partitioning of the chaperone (Figures $7 \mathbf{B}$ and $5 A$, orange). In budded cells, which are efficiently cured (Figure 6 G), only $~ 8 \%$ of cells had resolved heat-induced Hsp104-GFP foci by the time the cell divided (Figure 7B[105 min], Figure 7C), leading to the asymmetric retention of Hsp104-GFP (Figures 7B and 5A, gray). Together, these observations indicate that Hsp104 is retained in cells exposed to elevated temperature if it is unable to resolve its heat-induced substrates prior to cell division. Because sensitivity to curing at elevated temperature correlated with cell-cycle stage (Figure 6F,G) and Hsp104-GFP localization to these cytoplasmic foci (Figure 5), substrate-chaperone dynamics must create a temporal limitation on proteostasis capacity.

\section{Discussion}

In Saccharomyces cerevisiae, expression of the molecular chaperone Hsp104, even at its low basal level, reduces organismal fitness at the normal growth temperature; however, survival at elevated temperatures is absolutely dependent on Hsp104, whose expression is induced to high levels by heat shock (Sanchez et al., 1992; Escusa-Toret et al., 2013). Thus, cell-based limitations must finely tune proteostasis capacity not only to control protein misfolding induced by stress but also to allow normal protein folding in the absence of these challenges (Morimoto, 2008). Using the yeast prion $\left[\mathrm{PSI}^{+}\right]$as a model to understand the in vivo interactions between amyloid and POC pathways, we have uncovered one such pathway. While $\left[P S I^{+}\right]^{\text {Weak }}$ is mitotically stable at the normal growth temperature ( 3\% loss) (Derkatch et al., 1996), a transient sub-lethal thermal stress induces quantitative curing (Figure 1 and Figure 8) through the disassembly of existing Sup35 amyloid by Hsp104 (Figures 1, 2 and 8). Our studies indicate that the increase in Hsp104 expression at elevated temperature alone is not sufficient to induce Sup35 amyloid resolution and [PSI+] $]^{\text {Weak }}$ curing (Figures 1, 3). Rather, Hsp104 must engage heat-induced protein aggregates for a period that exceeds the time to the next cell division (Figures 7, 8). As a result, Hsp104 is asymmetrically localized to the cells that experienced the thermal stress (Figures 5, 8), and this increase in chaperone accumulation, along with its activity, promotes curing in the same cells (Figures 5, 8). Thus, chaperone spatial engagement, substrate 


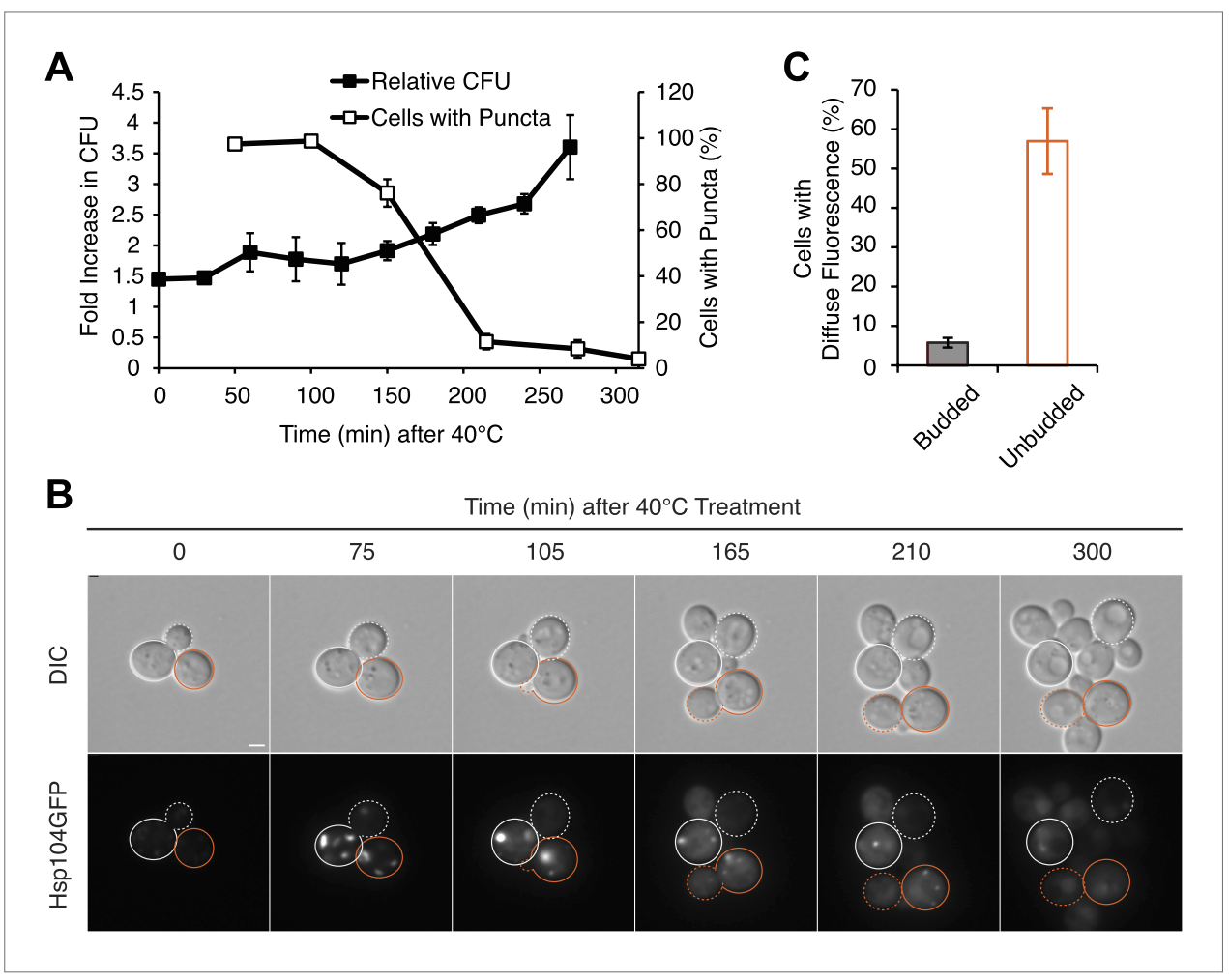

Figure 7. Substrate-chaperone engagement must exceed time to cell division to induce curing. (A) The number of $\left[\right.$ PSI+] ${ }^{\text {Weak }}$ HSP104GFP (SY2126) cells containing fluorescent foci was quantified in cultures recovering at $30^{\circ} \mathrm{C}$ over time following a $90 \mathrm{~min}$ incubation at $40^{\circ} \mathrm{C}$ (white). Colony forming units in these cultures were quantified by plating (black). Data represent means; error bars represent standard deviations; $n=3$. (B) $\left[P S I^{+}\right]^{\text {Weak }}$ HSP104GFP cells (SY2126) treated for $30 \mathrm{~min}$ at $40^{\circ} \mathrm{C}$ and imaged over time in a microfluidics chamber are shown. Cells that were budded at the time of thermal stress are outlined in white, while unbudded cells are outlined in orange. Solid lines mark mothers, and dotted lines mark daughters. Scale bar $=1 \mu \mathrm{m}$. (C) A [PSI+] Weak HSP104GFP strain (SY2126) was imaged over time in a microfluidics at $30^{\circ} \mathrm{C}$ after a $30 \mathrm{~min}$ incubation at $40^{\circ} \mathrm{C}$ chamber. Budded or unbudded cells were scored at the first cell division for the presence or absence of fluorescent aggregates. Data represent means; error bars represent standard deviations; $n=3 ; p=0.0005$ by unpaired t-test.

DOI: 10.7554/eLife.04288.015

processing dynamics, and partitioning during cell division represent cell based limitations on proteostasis capacity.

Metazoans lack an Hsp104 homolog (Torrente and Shorter, 2013), but disaggregase activity has also recently been linked to a multi-component system in yeast comprised of Hsp110, Hsp70, and Hsp40, and this activity is conserved in the C. elegans and human homologs of these chaperones (Shorter, 2011; Rampelt et al., 2012; Mattoo et al., 2013). This system is largely ineffective in the disaggregation of amyloid in vitro (Shorter, 2011) but can promote the slow disassembly of amyloid from fiber ends in the presence of small heat shock proteins, such as Hsp26 and Hsp42 from yeast or HspB5 from humans (Duennwald et al., 2012). Like Hsp104 in yeast, Hsp110 localizes to foci containing misfolded protein in human cells following thermal stress (Rampelt et al., 2012) and interacts with protein amyloids in vivo (Ishihara et al., 2003; Wang et al., 2009; Olzscha et al., 2011), raising the possibility that Hsp110 engagement with stress-induced substrates could also promote its activity toward amyloidogenic substrates in vivo.

The spatial engagement of PQC factors, including both chaperones and components of the ubiquitin-proteasome system, is a newly appreciated consequence of their function in vivo. Numerous cytoplasmic foci arise in response to stressors including heat, aging, oxidation, and/or proteasome inhibition. These foci include aggresomes, the insoluble protein deposit (IPOD), the juxtanuclear quality control compartment (JUNQ), StiF-inducible foci (StiF), and Q-bodies, the latter of which form under the mild thermal stress conditions employed in our studies (Johnston et al., 1998; Erjavec et al., 2007; 


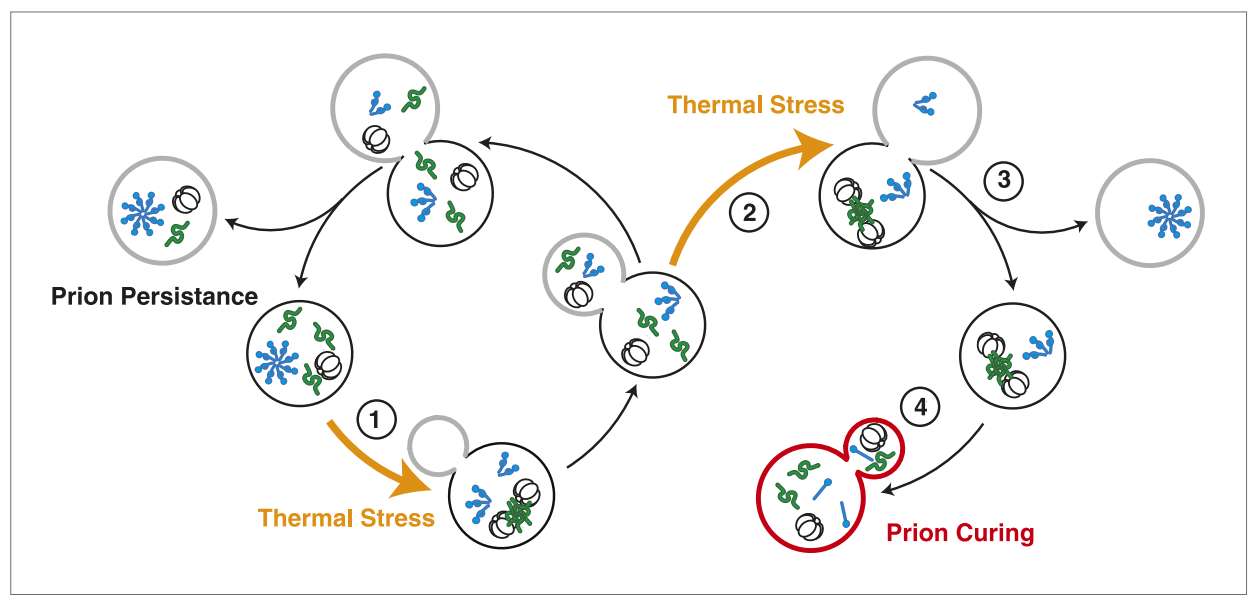

Figure 8. Model for Sup35 amyloid resolubilization and curing upon thermal stress. Upon thermal stress, cellular proteins (green) misfold and aggregate, leading to the induction and recruitment of Hsp104 (barrel). If thermal stress occurs in unbudded cells (1), these aggregates are resolved prior to cell division, allowing the partitioning of Hsp104 to both mother (black) and daughter (gray) cells (left). If thermal stress occurs in budded cells (2), heatinduced aggregates persist upon cell division (3), leading to the asymmetric retention of Hsp104 in mother cells. Both heat-induced aggregates (green) and Sup35 amyloid (blue corkscrews) are resolved in cells accumulating high levels of Hsp104, leading to curing (red, 4).

DOI: 10.7554/eLife.04288.016

Kaganovich et al., 2008; Liu et al., 2010; Specht et al., 2011; Malinovska et al., 2012; Weisberg et al., 2012; Escusa-Toret et al., 2013; Wolfe et al., 2013). While the relationship of each of these foci to one another is currently unclear, they are all defined by the co-localization of misfolded and/or aggregation-prone proteins with PQC factors, some of which can be found in more than one of type of focus. The PQC factors that localize to these foci, such as Hsp104, clearly promote survival under stress (Sanchez et al., 1992; Escusa-Toret et al., 2013), but whether their localization into cytoplasmic foci specifically altered proteostasis capacity had not been previously established. Our studies indicate that the engagement of Hsp104 with heat-induced misfolded protein aggregates enhances proteostasis capacity by increasing the accumulation of this factor beyond the level attainable by changes in gene expression (Figure 5) and thereby permitting the disassembly of existing Sup35 amyloid (Figures 1,5).

While our studies indicate that chaperone partitioning imposes a limitation on proteostasis capacity, other aspects of this process may be more relevant to this upper boundary in post-mitotic cells, such as neurons. Indeed, our observations reveal other cell-based limitations beyond chaperone partitioning. For example, in contrast to the proteostasis enhancement we observe following thermal stress in yeast, previous studies have linked the accumulation of protein aggregates to reduced proteostasis capacity in vivo (Broadley and Hartl, 2009). In these cases, protein aggregates, including those resulting from oxidative damage with age or proteotoxic stresses, have been linked to reduced replicative lifespan, (Aguilaniu et al., 2003; Hernebring et al., 2006; Rujano et al., 2006; Erjavec et al., 2007, 2008; Tessarz et al., 2009; Knorre et al., 2010; Liu et al., 2010; Unal et al., 2011; Zhou et al., 2011; Spokoini et al., 2012) and, the presence of protein amyloids, such as polyglutamineexpanded proteins and other yeast prions, promote the misfolding of metastable proteins, interfere with proteolysis, reduce protein synthesis, inhibit endocytosis, and disrupt prion propagation through the sequestration of chaperones (Gidalevitz et al., 2006; Meriin et al., 2003; Kirstein-Miles and Morimoto, 2013; Park et al., 2013; Yang et al., 2013; Yu et al., 2014). A comparison of these studies with our work suggests that the dynamics of chaperone engagement with distinct substrates, rather than simply their presence, correlates with the impact of these interactions on proteostasis capacity. In the studies resulting in chaperone sequestration, proteotoxicity correlates with imbalances in the system imposed by harsh conditions and/or the unnaturally high expression of amyloidogenic proteins. In contrast, we detect no differences in Hsp104-GFP localization in [PSI+ ${ }^{+}$and [psi ${ }^{-}$] strains expressing Sup35 at its endogenous level (Figure $4 \mathbf{A}, 30^{\circ} \mathrm{C}$ ), and Sup35 amyloid can clearly be resolved at these native stoichiometries when the system is elevated to a distinct but accessible 
proteostatic niche (Figure 1D). However, paralleling the studies in metazoans, $\left[\mathrm{PSI}^{+}\right]$can transition from a benign to a toxic state upon Sup35 overexpression (Ter-Avanesyan et al., 1993), a condition that also induces Hsp70 co-localization (Winkler et al., 2012). Thus, proteostasis capacity appears to be finely tuned to maintain a natively expressed proteome.

Additional evidence of the importance of this balance can be gleaned by a comparison of chaperone overexpression in different cellular contexts. For example, overexpression of Hsp104 alone, to the same level achieved here through asymmetric retention of this factor (Table 1 and Figure 3figure supplement 1C), also induces curing (Chernoff et al., 1995; Wegrzyn et al., 2001). While it has been suggested that Hsp104 overexpression dissolves Sup35 amyloid in vivo, this interpretation is complicated by a lack of temporal resolution and the ability to monitor existing protein (Park et al., 2014) and is inconsistent with the increase in the size of SDS-resistant Sup35 aggregates under these conditions (Figure 3-figure supplement 1D) (Kryndushkin et al., 2003). An alternative model, which is consistent with this biochemical evidence of Hsp104 inhibition, suggests that upon its overexpression, Hsp104 aberrantly and non-productively co-localizes with Sup35 amyloid (Chernoff et al., 1995; Kryndushkin et al., 2003; Bagriantsev et al., 2008; Winkler et al., 2012). In contrast, our studies indicate that Hsp104 overexpression within the context of a thermal stress transitions Sup35 amyloid from outside the buffering capacity of the proteostasis network to within its sphere of protection. Notably, Hsp104 co-localization with Sup35 amyloid varies based on its mode of overexpression (i.e. individual vs network up-regulation), again implicating substrate-chaperone dynamics, rather than simply chaperone availability, in proteostasis capacity. Intriguingly, this interplay is distinct for individual PQC factors within the same cell, as thermal stress induces localization of Hsp104, Ssa1, and Sis1 to cytoplasmic foci, but only Hsp104 is asymmetrically retained upon cell division (Figure 5-figure supplement 1D, E), suggesting an additional point of proteostasis regulation.

Beyond these cell-based limitations on proteostasis capacity, our studies have deconvoluted the contributions of distinct physical characteristics of amyloid variants to their ability to exceed the PQC buffering capacity in vivo. Intriguingly, we find that $\left[\mathrm{PSI}^{+}\right]^{\text {Weak }}$, the more thermodynamically stable but less efficiently amplified variant of Sup35 amyloid (Tanaka et al., 2006), is susceptible to curing at elevated temperature, while the less thermodynamically stable and more efficiently amplified $\left[\mathrm{PSI}^{+}\right]^{\text {Strong }}$ variant is not (Figure 1), indicating that amyloid amplification rather than stability imposes the primary limitation on amyloid clearance. Consistent with this idea, reducing $\left[\mathrm{PSI}^{+}\right]^{\text {Strong }}$ amplification by either expressing a Sup35 mutant or decreasing the expression of wild-type Sup35 promotes curing at elevated temperature (Figure 2). Thus, manipulations that have minor effects on the dynamics of existing amyloid are also sufficient to move this alternative protein-folding pathway within the buffering capacity of the proteostasis network.

Together, our observations suggest an alternative to the view that the physical characteristics of amyloid complexes alone preclude their accessibility to the cell's natural defenses against protein misfolding. Rather, the dynamics and balance of the system as a whole, including both protein-based and cell-based contributors, create not only a niche that allows amyloid to arise and persist but also another that promotes amyloid clearance. Our studies, therefore, raise the possibility that the proteostasis limitations that allow the accumulation of chronically misfolded proteins may be distinct in a native context and under conditions of their overexpression. Within this framework, our studies provide a proof-of-principle example to support the idea that proteostasis regulators, which are aimed at transitioning proteostasis landscapes to new thresholds, may be the most effective interventions into amyloidosis (Lindquist and Kelly, 2011).

\section{Materials and methods}

\section{Plasmid and strain construction}

All plasmids used in this study were previously reported (Table 2) except for SB1013 (pRS306P GPD $\mathrm{FFL}$ mCherry), which contains firefly luciferase as an $\mathrm{Xba1/BamHI}$ fragment and mCherry as a BamHI/Xhol fragment, separated by a three-repeat glycine-serine linker. The ORFs were amplified by PCR using primers 5Xbal firefly/3BamHI firefly and 5BamHIGS3mCherry/3XholmCherry, respectively (Table 3) and confirmed by sequencing. All strains of Saccharomyces cerevisiae used in this study are derivatives of 74-D694 (Table 4) (Chernoff et al., 1995). A WT [PSI+] ${ }^{\text {Weak }}$ diploid strain (SY945) was generated by mating SY2600 with SLL3252 (Table 4). The diploid state was confirmed by sporulation. SY591, a $\left[\mathrm{PSI}^{+}\right]^{\text {Weak }}$ strain containing a heterozygous deletion of HSP104, was created by transformation of a 
Table 2. Plasmids

\begin{tabular}{|c|c|}
\hline Name & Description \\
\hline SB20 & $\mathrm{pRS} 306-\mathrm{P}_{\text {Sup } 35} \mathrm{~N}(\mathrm{GS})_{3} \mathrm{SGFP}(\mathrm{GS})_{3} \mathrm{MC}$ \\
\hline SB503 & pRS304-P ${ }_{G P D} G S T-D s R E D-N L S$ \\
\hline SB630 & pRS306- $\mathrm{P}_{\text {GAL }} \mathrm{Hsp} 104$ \\
\hline SB657 & pRS306- $\mathrm{P}_{\text {tetO2 }}$ Sup35 \\
\hline SB658 & pRS306-P teto2 $_{\text {Sup35(G58D) }}$ \\
\hline SB849 & pRS306- $P_{H S E} G F P$ \\
\hline SB1013 & pRS306-P GPD FFL-mCherry \\
\hline
\end{tabular}

DOI: 10.7554/eLife.04288.017 formants on medium lacking uracil. Galactose-inducible expression of Hsp104 was confirmed by western blotting. $\left[\mathrm{PSI}^{+}\right]^{\text {Strong }}$ and $\left[\mathrm{PSI}^{+}\right]^{\text {Weak }}$ were then cytoduced into this strain from SY1698 and SY1699, respectively, to create SY1748 and SY1749 (Table 4), respectively (Conde and Fink, 1976). Cytoductants were selected by growth on synthetic medium containing glycerol and lacking uracil and by colony color on YPD. The HSP104-GFP [psi'] strain (SY2125) was created by transforming a PCR-generated cassette using pFA6a-GFP(S65T)-KanMX6 as a template with primers HSP104-GFP F-A and HSP104GFP R-A (Table 3) into WT [PSI+ $]^{\text {Strong }}$ strains and selection on medium containing $300 \mu \mathrm{g} / \mathrm{ml} \mathrm{G} 418$. Integration was confirmed by PCR using primers Hsp104for/GFP-R and pFa6 test/Hsp104 3 flank R (Table 3), and expression was confirmed by fluorescence microscopy. These strains were cured of the prion by growth on YPD plates containing $3 \mathrm{mM} \mathrm{GdnHCl}$ (Tuite et al., 1981). The [PSI+] $]^{\text {Weak }}$ variant (SY2126) was generated by mating SY2125 to a WT [PSI+] ${ }^{\text {weak }}$ strain (SLL2600) and sporulation. Tetrads were dissected to recover haploids, and HSP104-GFP isolates were verified by G418 resistance, fluorescence microscopy, and quantitative immunoblotting for Hsp104. The heat inducible GFP strain (SY2091) was generated by transformation of a WT [psi'] strain (SLL2119) with Bsu36l-digested SB849 (Table 2). Expression was confirmed by fluorescence microscopy. SSA1-GFP (SY2658) and SIS1-GFP (SY2447) $\left[P S I^{+}\right]^{\text {Weak }}$ strains were created by transforming PCR-generated cassettes using pFA6aGFP(S65T)-KanMX6 as a template with primers GFP-GS-Ssa1-F/GFP-Ssa1-R or Sis1-GFP-F GS/Sis1GFP-R (Table 3), respectively, into WT [PSI+ $]^{\text {Strong }}$ strains and selection on medium containing $300 \mu \mathrm{g} / \mathrm{ml}$ G418. Expression was confirmed by fluorescence microscopy and quantitative immunoblotting for Ssa1/2 and Sis1, respectively. These strains were cured of the prion by growth on YPD plates containing $3 \mathrm{mM} \mathrm{GdnHCl}$, mitochondrial loss was induced by growth in $25 \mu \mathrm{g} / \mathrm{ml}$ ethidium bromide, and [PSI $\left.{ }^{+}\right]^{\text {Weak }}$ was transferred to them by cytoduction (Cox, 1965), using SY1699 as a donor strain. Cytoductants were selected by growth on glycerol medium and $\left.300 \mu \mathrm{g} / \mathrm{ml} \mathrm{G418.} \mathrm{SSA1-GFP} \mathrm{and} \mathrm{SIS1-GFP} \mathrm{[PSI}{ }^{+}\right]^{\text {Weak }}$ strains containing a nuclear-localized fluorescent reporter protein (DsRed-NLS, SY2659, and SY485, respectively) were generated by transforming SY2658 or SY2447 with Bsu36l-digested SB503 (Table 2). Expression was confirmed by fluorescence microscopy. The $\triangle b$ ini [PSI+] ${ }^{\text {weak }}$ strain (SY1888) was created by transforming a PCR-generated cassette using pFA6a-KanMX4 as a template with primers AD-BNI1-f and AD-BNI1-r (Table 3) into a [PSI+] $]^{\text {Weak }}$ diploid (SY782, a cross between SY2600 and SY86, Table 4). Transformants were selected on medium containing $300 \mu \mathrm{g} / \mathrm{ml} \mathrm{G} 418$ and verified by PCR using primers AD-BNI1-fseq/PTEFCH and AD-BNI1-rseq/pFa6 test (Table 3). The haploid $\Delta$ bni1 $\left[P S I^{+}\right]^{\text {Weak }}$ strain was then generated by sporulation and tetrad dissection and verified by G418 resistance. The HSP104-GFP $\triangle$ bni1 [PSI+] ${ }^{\text {Weak }}$ strain (SY2486) was created by transforming SY2126 with a PCR-generated cassette using pFA6a-hphMX4 as a template with primers AD-BNI1-f and AD-BNI1-r (Table 3). Transformants were confirmed by PCR using primers AD-BNI1-fseq/PTEFCH and AD-BNI1-rseq/pFa6 test (Table 4) and growth on YPD plates containing $300 \mu \mathrm{g} / \mathrm{ml}$ hygromycin B.

\section{Growth conditions and phenotypic analysis}

Unless otherwise specified, yeast cultures were grown in rich YPD medium supplemented with $0.3 \mathrm{mM}$ adenine. Cultures were maintained at an $\mathrm{OD}_{600}$ of less that 0.5 at $30^{\circ} \mathrm{C}$ for at least 10 doublings to ensure exponential growth. Where indicated, cultures were then transferred to $37^{\circ} \mathrm{C}$ or $40^{\circ} \mathrm{C}$ for the specified period. Pretreatment of cultures at $37^{\circ} \mathrm{C}$ prior to shift to $40^{\circ} \mathrm{C}$ was for $30 \mathrm{~min}$. To analyze colony color phenotype, aliquots of cultures were diluted in $\mathrm{H}_{2} \mathrm{O}$ as needed to ensure well-separated single colonies 
Table 3. Primers

\begin{tabular}{|c|c|}
\hline Name & Sequence \\
\hline 5Xbal firefly & 5'-TCTAGAATGGAAGATGCCAAAAACATTAAG-3' \\
\hline 3BamHI firefly & 5'-GGATCCACCTTGAGACTGTGGTTGGAAAC-3' \\
\hline 5BamHI GS3mCherry & 5'-GGATCCGGTAGTGGTAGTGGTAGTATGGTGAGCAAGGG CGAGGAG-3' \\
\hline 3Xhol mCherry & 5'-CTCGAGTTACTTGTACAGCTCGTCCATGCCG-3' \\
\hline SD27 & $\begin{array}{l}\text { 5'-ACTTGCTCGGAATAACATCTATATCTGCCCACTAGCAACA } \\
\text { CAGCTGAAGCTTCGTACGC-3' }\end{array}$ \\
\hline SD28 & $\begin{array}{l}\text { 5'-GGTATTATTGTGTTTGCATTTACTTATGTTTGCAAGAAATG } \\
\text { CATAGGCCACTAGTGGATCTG-3' }\end{array}$ \\
\hline Psup352 & 5'-GAGATGCTCATCAAGGG-3' \\
\hline PTEFCH & 5'-GCACGTCAAGACTGTCAAGG-3' \\
\hline Sup35 3'chk & 5'-TATTTACGAAGGAGACCCGGAG-3' \\
\hline pFab test & 5'-TGCCCAGATGCGAAGTTAAGTG-3' \\
\hline HSP104-GFP F-A & $\begin{array}{l}\text { 5'-CGATAATGAGGACAGTATGGAAATTGATGATGACCTA } \\
\text { GATCGGATCCCCGGGTTAATTAA-3' }\end{array}$ \\
\hline Hsp104-GFP R-A & $\begin{array}{l}\text { 5'-TATTATATTACTGATTCTTGTTCGAAAGTTTTTAAAAATC } \\
\text { GAATTCGAGCTCGTTTAAAC-3' }\end{array}$ \\
\hline Hsp104for & 5'-GGCACATCCTGATGTTTTGA-3' \\
\hline GFP-R & 5'-ССТTCAСССТСТССАСТGACAG-3' \\
\hline Hsp104 3 flank R & 5'-CCGTATTCTAATAATGGACCAATC-3' \\
\hline GFP-GS-Ssa1-F & $\begin{array}{l}\text { 5'-AGCTCCAGAGGCTGAAGGTCCAACCGTTGAAGAAGTTG } \\
\text { ATGGTTCTGGTTCTGGTTCTCGGATCCCCGGGTTAATTAA-3' }\end{array}$ \\
\hline GFP-Ssa1-R & $\begin{array}{l}\text { 5'-ACCCAGATCATTAAAAGACATTTTCGTTATTATCAATTGC } \\
\text { GAATTCGAGCTCGTTTAAAC-3' }\end{array}$ \\
\hline Sis1-GFP-F GS & $\begin{array}{l}\text { 5'-ACTAAACGACGCTCAAAAACGTGCTATAGATGAAAATTT } \\
\text { TGGTTCTGGTTCTGGTTCTCGGATCCCCGGGTTAATTAA-3' }\end{array}$ \\
\hline Sis1-GFP-R & $\begin{array}{l}\text { 5'-ATTTATTTGAGTTTATAATTATATTTGCTTAGGATTACTAG } \\
\text { AATTCGAGCTCGTTTAAAC-3' }\end{array}$ \\
\hline AD-BNI1-f & $\begin{array}{l}\text { 5'-ATGTTGAAGAATTCAGGCTCCAAACATTCGAACTCAAAG } \\
\text { GCAGCTGAAGCTTCGTACGC-3' }\end{array}$ \\
\hline AD-BNI1-r & $\begin{array}{l}\text { 5'-TTATTTGAAACTTAGCCTGTTACCTGTCCTAGCCTCACCT } \\
\text { GCATAGGCCACTAGTGGATCTG-3' }\end{array}$ \\
\hline AD-BNI1-fseq & 5'-GACATCGGTTAGAGGAAG-3' \\
\hline AD-BNI1-rseq & 5'-CACTGTGCTTGTCACTTA-3' \\
\hline
\end{tabular}

upon plating to solid YPD medium. After growth at $30^{\circ} \mathrm{C}$, each colony was scored based on colony color phenotype: fully cured (completely red, [psi $\left.\left.{ }^{-}\right]\right)$, sectored (part red and part white), or [PSl'] (completely white). Unless otherwise indicated, fully cured and sectored colonies were combined in the 'cured' category. For all colony counting assays, at least 150 colonies were counted for each experimental condition/ timepoint. For the galactose-inducible Hsp104 experiments, cells were grown in rich YP medium containing $3 \%$ raffinose supplemented with $3 \%$ galactose during induction. $\alpha$-factor and nocodazole arrests were performed in YPD liquid medium containing final concentrations of $5 \mu \mathrm{g} / \mathrm{ml} \mathrm{\alpha}$-factor or $15 \mu \mathrm{g} / \mathrm{ml}$ nocodazole, respectively, for $\sim 2 \mathrm{hr}$. Following confirmation of arrest based on cell morphology by bright-field microscopy, cultures were washed three times with medium containing $1 \mathrm{mM}$ DMSO followed by one wash in YPD before resuspension for indicated manipulation. $\mathrm{GdnHCl}$ treatment was performed at $3 \mathrm{mM}$ final concentration in liquid YPD, and for experiments involving recovery, cultures were washed three times with medium before resuspension in YPD for indicated manipulation.

\section{Protein analysis}

SDS-PAGE and quantitative immunoblotting were performed as previously described (Pezza et alo, 2009). Anti-Ssa1/2 rabbit serum was provided by E. Craig (U Wisconsin-Madison), and anti-Sis1 rabbit 
Table 4. Yeast strains

\begin{tabular}{|c|c|c|c|c|}
\hline Strain & Genotype & $\begin{array}{l}\text { Plasmids } \\
\text { integrated }\end{array}$ & Reference & Figure \\
\hline SLL2119 & $\begin{array}{l}\text { MATa }\left[\mathrm{psi}^{-}\right] \text {ade1-14 his3 } \mathbf{\Delta} 200 \\
\text { trp1-289 ura3-52 leu2-3, } 112\end{array}$ & - & Chernoff et al., 1995 & $1 c, 3 S f$ \\
\hline SLL2600 & $\begin{array}{l}\text { MATa }\left[\mathrm{PSI}^{+}\right]^{\text {Weak }} \text { ade1-14 his3 } \Delta 200 \\
\text { trp1-289 ura3-52 leu2-3, } 112\end{array}$ & - & Derkatch et al., 1996 & $\begin{array}{l}\text { 1, 2a, 3, 5ce, 6abcfg, } \\
1 \mathrm{~S}, 3 \mathrm{Sabg}, 4 \mathrm{Sabcd}, \\
5 \mathrm{Sfg}, 6 \mathrm{Sa}\end{array}$ \\
\hline SLL2606 & $\begin{array}{l}\text { MATa }\left[P S I^{+}\right]^{\text {Strong }} \text { ade } 1-14 \text { his3 } \Delta 200 \\
\text { trp1-289 ura3-52 leu2-3, } 112\end{array}$ & - & Chernoff et al., 1995 & $1 \mathrm{ac}, 3 \mathrm{sf}$ \\
\hline SLL3071 & $\begin{array}{l}\text { MATa/ } \alpha\left[P S I^{+}\right]^{\text {strong }} \text { ade } 1-14 / a d e 1-14 \\
\text { his3 } \Delta 200 / \text { his3 } \Delta 200 \text { trp1-289/trp1-289 } \\
\text { ura3-52/ura3-52 leu2-3112/leu2-3112 }\end{array}$ & - & DiSalvo et al., 2011 & $2 d$ \\
\hline SLL3252 & $\begin{array}{l}\text { MATa [psi-] ade1-14 his3 } \Delta 200 \\
\text { trp1-289 ura3-52 leu2-3, } 112\end{array}$ & - & Chernoff et al., 1995 & $\begin{array}{l}\text { 'Materials and } \\
\text { methods' }\end{array}$ \\
\hline SY86 & $\begin{array}{l}\text { MATa [psi-] ade1-14 his3 } \Delta 200 \\
\text { trp1-289 ura3-52 leu2-3, } 112 \\
\text { sup35::N(GS) }{ }_{3} \text { GFP(GS) }{ }_{3} M C\end{array}$ & SB20 & Derdowski et al., 2010 & $\begin{array}{l}\text { 'Materials and } \\
\text { methods' }\end{array}$ \\
\hline SY197 & $\begin{array}{l}\text { MATa [psi'] ade1-14 his3-11,-15 } \\
\text { trp1-1 ura3-1 leu2-3112 can1-100 }\end{array}$ & - & J Weissman (YJW513) & $\begin{array}{l}\text { 'Materials and } \\
\text { methods' }\end{array}$ \\
\hline SY591 & $\begin{array}{l}\text { MATa/a [PSI+'] Weak ade1-14/ade1-14 } \\
\text { his3D200/his3 } 200 \text { TRP/trp1-289 } \\
\text { ura3-52/ura3-52 leu2-3112/leu2-3112 } \\
\text { HSP104/hsp104::LEU2 }\end{array}$ & - & This study & $2 b$ \\
\hline SY782 & 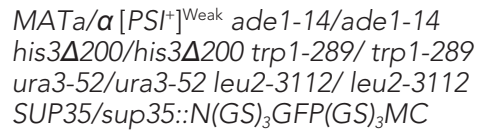 & - & This study & $\begin{array}{l}\text { 'Materials and } \\
\text { methods' }\end{array}$ \\
\hline SY945 & 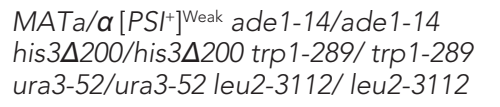 & - & This study & $2 b$ \\
\hline SY957 & 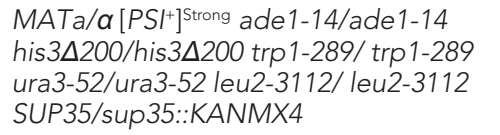 & - & This study & $2 d$ \\
\hline SY1646 & $\begin{array}{l}\text { MATa/ } \alpha\left[P S I^{+}\right]^{\text {Strong }} \text { ade 1-14/ade1-14 } \\
\text { his3 } \Delta 200 / \text { his3 } 3200 \text { trp 1-289/ trp1-289 } \\
\text { ura3-52/ura3-52::URA3:: } \text { teto2 SUP35 } \text { leu2-3112/ leu2-3112 SUP35/ } \\
\text { sup35::KANMX4 }\end{array}$ & SB657 & DiSalvo et al., 2011 & $2 c$ \\
\hline SY1648 & $\begin{array}{l}\text { MATa/ } \alpha\left[P S I^{+}\right]^{\text {Strong }} \text { ade1-14/ade1-14 } \\
\text { his3 } 200 / \text { his3 } 3200 \text { trp1-289/ trp1-289 } \\
\text { ura3-52/ura3-52::URA3:: } \text { teto2 } \\
\text { SUP35(G58D) leu2-3112/ leu2-3112 } \\
\text { SUP35/sup35::KANMX4 }\end{array}$ & SB658 & DiSalvo et al., 2011 & $2 c$ \\
\hline SY1698 & $\begin{array}{l}\text { MATa }\left[P S I^{+}\right]^{\text {Strong }} \text { ade1-14 his } 3 \Delta 200 \\
\text { ura3-52 leu2-3 kar1-d15 ConR CyhR }\end{array}$ & - & This study & $\begin{array}{l}\text { 'Materials and } \\
\text { methods' }\end{array}$ \\
\hline SY1699 & $\begin{array}{l}\text { MATa }\left[P S I^{+}\right]^{\text {Weak }} \text { ade1-14 his } 3 \Delta 200 \\
\text { ura3-52 leu2-3 kar1-d15 ConR CyhR }\end{array}$ & - & This study & $\begin{array}{l}\text { 'Materials and } \\
\text { methods' }\end{array}$ \\
\hline SY1748 & $\begin{array}{l}\text { MATa }\left[P S I^{+}\right]^{\text {Strong }} \text { ade } 1-14 \text { his3-11,-15 } \\
\text { trp1-1 ura3-1::URA3:: } P_{\text {GAL }} \text { HSP104 } \\
\text { leu2-3112 can1-100 }\end{array}$ & SB630 & This study & $3 \mathrm{Se}$ \\
\hline SY1749 & $\begin{array}{l}\text { MATa [PSI+] Weak ade1-14 his3-11,-15 } \\
\text { trp1-1 ura3-1::URA3:: } P_{\text {GAL }} \text { HSP104 } \\
\text { leu2-3112 can1-100 }\end{array}$ & SB630 & This study & 3Scde \\
\hline SY1888 & $\begin{array}{l}\text { MATa }\left[P S I^{+}\right]^{\text {Weak }} \text { ade1-14 his3 } \Delta 200 \\
\text { trp1-289 ura3-52 leu2-3, } 112 \\
\Delta \text { bni1::KANMX4 }\end{array}$ & - & This study & $5 c, 5 \mathrm{Sfg}$ \\
\hline SY2091 & $\begin{array}{l}\text { MATa [psi-] ade1-14 his3 } \Delta 200 \text { trp1-289 } \\
\text { ura3-52::URA:: } P_{\text {HSE }} \text { GFP leu2-3, } 112\end{array}$ & SB849 & This study & $5 \mathrm{Sa}$ \\
\hline
\end{tabular}

Table 4. Continued on next page 
Table 4. Continued

\begin{tabular}{|c|c|c|c|c|}
\hline Strain & Genotype & $\begin{array}{l}\text { Plasmids } \\
\text { integrated }\end{array}$ & Reference & Figure \\
\hline SY2125 & $\begin{array}{l}\text { MATa [psi'] ade1-14 his } 3 \Delta 200 \\
\text { trp1-289 ura3-52 leu2-3112 } \\
\text { HSP104GFP::KANMX6 }\end{array}$ & - & This study & $4 b$ \\
\hline SY2126 & $\begin{array}{l}\text { MATa }\left[P S I^{+}\right]^{\text {Weak }} \text { ade1-14 his } 3 \Delta 200 \\
\text { trp1-289 ura3-52 leu2-3112 } \\
\text { HSP104GFP::KANMX6 }\end{array}$ & - & This study & $\begin{array}{l}\text { 4, 5abdfg, 6de, } 7 \\
\text { 4Sabcdfg, 6Sb }\end{array}$ \\
\hline SY2447 & $\begin{array}{l}\text { MATa }\left[P S I^{+}\right]^{\text {Weak }} \text { ade1-14 his } 3 \Delta 200 \\
\text { trp1-289 ura3-52 leu2-3112 } \\
\text { SIS1GFP::KANMX6 }\end{array}$ & - & This study & $5 \mathrm{Se}$ \\
\hline SY2485 & $\begin{array}{l}\text { MATa }\left[P S I^{+}\right]^{\text {Weak }} \text { ade } 1-14 \text { his } 3 \Delta 200 \\
\text { trp1-289::TRP::P } \text { GPD GST-DsRed-NLS }_{\text {Gra3-52 leu2-3112 SIS1GFP::KANMX6 }}\end{array}$ & SB503 & This study & $5 \mathrm{Sc}$ \\
\hline SY2486 & $\begin{array}{l}\text { MATa [PSI+] }{ }^{\text {Weak }} \text { ade1-14 his3 } \Delta 200 \\
\text { trp1-289 ura3-52 leu2-3, } 112 \\
\text { HSP104GFP::KANMX6 } \Delta \text { bni1::hphMX4 }\end{array}$ & - & This study & $5 b$ \\
\hline SY2658 & $\begin{array}{l}\text { MATa }\left[P S I^{+}\right]^{\text {Weak }} \text { ade1-14 his3 } 3200 \\
\text { trp1-289 ura3-52 leu2-3112 } \\
\text { SSA1GFP::KANMX6 }\end{array}$ & - & This study & $5 S d$ \\
\hline SY2659 & $\begin{array}{l}\text { MATa }\left[P S I^{+}\right]^{\text {Weak }} \text { ade1-14 his3 } 3200 \\
\text { trp 1-289::TRP:: } P_{G P D} \text { GST-DsRed-NLS } \\
\text { ura3-52 leu2-3112 SSA1GFP::KANMX6 }\end{array}$ & SB503 & This study & $5 \mathrm{Sb}$ \\
\hline SY2802 & $\begin{array}{l}\text { MATa }\left[P S I^{+}\right]^{\text {Weak }} \text { ade } 1-14 \text { his } 3 \Delta 200 \\
\text { trp1-289 ura3-52::URA:::P } \\
\text { Firefly-mCherry leu2-3112 } \\
\text { HSP104GFP::KANMX6 }\end{array}$ & SB1013 & This study & $4 \mathrm{Se}$ \\
\hline
\end{tabular}

DOI: 10.7554/eLife.04288.019

serum was provided by M. Tuite (U Kent, Canterbury, UK). Semi-native agarose gel electrophoresis (SDD-AGE) was performed as previously described (Kryndushkin et al., 2003). The cycloheximide SDS-sensitivity assay was performed as previously described (DiSalvo et al., 2011) with the following modifications: 1) cultures were treated at the various experimental temperatures for 30 min prior to the addition of cycloheximide to allow for the induction of chaperone proteins, and 2) after cycloheximide treatment, cultures were incubated with shaking at $30^{\circ} \mathrm{C}$ for $2 \mathrm{hr}$ before lysis and analysis. For the aggregation analysis, native lysates were prepared as described previously (Kryndushkin et al., 2003). Lysates were pre-cleared for $1 \mathrm{~min}$ at $500 \times \mathrm{g}$ and total protein content was quantified using the BioRad Bradford assay in triplicate. Lysates were subjected to $15,000 \times \mathrm{g}$ centrifugation for $15 \mathrm{~min}$, and pellets were washed with $10 \mathrm{mM}$ sodium phosphate buffer ( $\mathrm{pH} 7.5)$ containing 2\% NP-40 before being resuspended in $10 \mathrm{mM}$ sodium phosphate buffer (pH7.5) and quantified again in triplicate using the Bradford assay. For the Hsp104 immunocapture, native lysates were prepared at $4^{\circ} \mathrm{C}$ in IP buffer $(50 \mathrm{mM} \mathrm{HEPES}-\mathrm{NaOH}$ (pH 7.5), $150 \mathrm{mM} \mathrm{NaCl}, 10 \mathrm{mM} \mathrm{MgCl}, 1$ mM EDTA, 1\% NP-40, 0.25\% Na-deoxycholate, and protease inhibitors ( $2 \mathrm{mM}$ PMSF, $5 \mu \mathrm{g} / \mathrm{ml}$ pepstatin, complete protease inhibitor tablets (Pierce, Rockford, IL), protease inhibitor cocktail (Sigma-Aldrich, St. Louis, MO)). Lysates were pre-cleared for $1 \mathrm{~min}$ at $500 \times g$, and then incubated for $1 \mathrm{hr}$ with Protein G magnetic beads (NEB, Ipswich, MA) with nutation. Immunocapture was performed using Protein $\mathrm{G}$ magnetic beads and anti-GFP mouse monoclonal antibody (Roche, Switzerland). Beads were washed $4 \times$ with IP buffer and $1 \times$ with $50 \mathrm{mM} \mathrm{HEPES}-\mathrm{NaOH}$ $(\mathrm{pH} 7.5)$, and protein was eluted by boiling in SDS sample buffer. Co-captured proteins were resolved by SDS-PAGE and analyzed by gel staining with Flamingo (Bio-Rad, Hercules, CA) and fluorescent scanning on a Typhoon imager (GE Lifesciences, Marlborough, MA) according to the manufacturer's instructions or by western blot for GFP.

\section{Imaging and microfluidics}

Static images were obtained on a Zeiss Axio Imager M2 fluorescence light microscope equipped with a 100x objective. Confocal images were obtained on a Zeiss LSM 510 Meta confocal microscope using a $100 \times$ objective. Microfluidics experiments were performed on a Zeiss Axio Observer Z1 using 
a CellAsics microfluidics plate with temperature controls and media flow of 2 psi on a YOC4 yeast perfusion plate (channel size 3.5-5 $\mu \mathrm{m}$ ). Imaging was performed in complete minimal medium supplemented with $2 \%$ glucose and $2.5 \mathrm{mM}$ adenine. Fluorescence intensity was analyzed using the Zen software package (Zeiss, Germany).

\section{Flow Cytometry}

Flow cytometry and cell sorting was performed on a BD FACSAria fluorescence-activated cell sorter using a $488 \mathrm{~nm}$ laser and a FITC-A filter to measure GFP fluorescence intensity in single cells. Data were obtained at least in triplicate with representative spectra shown. Data were analyzed using the FlowJo software package (TreeStar Inc., Ashland, OR).

\section{Acknowledgements}

We thank Jeff Laney, members of the Serio and Laney laboratories, and Ulrich Hartl for helpful discussions and comments on the manuscript, and E Craig and M Tuite for antisera. This work was funded by awards from the NIH to TRS (R01 GM069802001), CLK (F31 AG034754), and CRL (F31 GM099383).

\section{Additional information}

Funding

\section{Funder}

National Institute of General Medical Sciences

\begin{tabular}{lll}
\hline National Institutes of Health & F31 AG034754 & Courtney L Klaips \\
\hline $\begin{array}{l}\text { National Institute of General } \\
\text { Medical Sciences }\end{array}$ & F31 GM099383 & Christine R Langlois \\
\hline
\end{tabular}

The funders had no role in study design, data collection and interpretation, or the decision to submit the work for publication.

Author contributions

CLK, Conception and design, Acquisition of data, Analysis and interpretation of data, Drafting or revising the article; MLH, CRL, Acquisition of data, Analysis and interpretation of data; TRS, Conception and design, Analysis and interpretation of data, Drafting or revising the article

\section{References}

Aguilaniu H, Gustafsson L, Rigoulet M, Nyström T. 2003. Asymmetric inheritance of oxidatively damaged proteins during cytokinesis. Science 299:1751-1753. doi: 10.1126/science.1080418.

Amon A. 2002. Synchronization procedures. Methods in Enzymology 351:457-467. doi: 10.1016/ S0076-6879(02)51864-4.

Bagriantsev SN, Gracheva EO, Richmond JE, Liebman SW. 2008. Variant-specific [PSI+] infection is transmitted by Sup35 polymers within $\left[\mathrm{PSI}^{+}\right]$aggregates with heterogeneous protein composition. Molecular Biology of the Cell 19:2433-2443. doi: 10.1091/mbc.E08-01-0078.

Broadley SA, Hartl FU. 2009. The role of molecular chaperones in human misfolding diseases. FEBS Letters 583:2647-2653. doi: 10.1016/j.febslet.2009.04.029.

Carmichael J, Chatellier J, Woolfson A, Milstein C, Fersht AR, Rubinsztein DC. 2000. Bacterial and yeast chaperones reduce both aggregate formation and cell death in mammalian cell models of Huntington's disease. Proceedings of the National Academy of Sciences of USA 97:9701-9705. doi: 10.1073/pnas.170280697.

Chai Y, Koppenhafer SL, Bonini NM, Paulson HL. 1999. Analysis of the role of heat shock protein (Hsp) molecular chaperones in polyglutamine disease. The Journal of Neuroscience 19:10338-10347.

Chernoff YO, Lindquist SL, Ono B, Inge-Vechtomov SG, Liebman SW. 1995. Role of the chaperone protein Hsp104 in propagation of the yeast prion-like factor $\left[\mathrm{PSI}^{+}\right]$. Science 268:880-884. doi: 10.1126/science.7754373.

Chiti F, Dobson CM. 2006. Protein misfolding, functional amyloid, and human disease. Annual Review of Biochemistry 75:333-366. doi: 10.1146/annurev.biochem.75.101304.123901.

Conde J, Fink GR. 1976. A mutant of Saccharomyces cerevisiae defective for nuclear fusion. Proceedings of the National Academy of Sciences of USA 73:3651-3655. doi: 10.1073/pnas.73.10.3651.

Cox B. 1965. [PSI], a cytoplasmic suppressor of super-suppression in yeast. Heredity 20:505-521. doi: 10.1038/ hdy. 1965.65. 
Cox BS, Tuite MF, Mclaughlin CS. 1988. The psi factor of yeast: a problem in inheritance. Yeast 4:159-178. doi: 10.1002/yea.320040302.

Cushman-Nick M, Bonini NM, Shorter J. 2013. Hsp104 suppresses polyglutamine-induced degeneration post onset in a drosophila Mjd/Sca3 model. PLOS Genetics 9:e1003781. doi: 10.1371/journal.pgen.1003781.

Derdowski A, Sindi SS, Klaips CL, DiSalvo S, Serio TR. 2010. A size threshold limits prion transmission and establishes phenotypic diversity. Science 330:680-683. doi: 10.1126/science.1197785.

Derkatch IL, Chernoff YO, Kushnirov VV, Inge-Vechtomov SG, Liebman SW. 1996. Genesis and variability of [PSI] prion factors in Saccharomyces cerevisiae. Genetics 144:1375-1386.

DiSalvo S, Derdowski A, Pezza JA, Serio TR. 2011. Dominant prion mutants induce curing through pathways that promote chaperone-mediated disaggregation. Nature Structural \& Molecular Biology 18:486-492. doi: 10.1038/ nsmb.2031.

Douglas PM, Summers DW, Ren HY, Cyr DM. 2009. Reciprocal efficiency of Rnq1 and polyglutamine detoxification in the cytosol and Nucleus. Molecular Biology of the Cell 20:4162-4173. doi: 10.1091/mbc.E09-02-0170.

Duennwald ML, Echeverria A, Shorter J. 2012. Small heat shock proteins potentiate amyloid dissolution by protein disaggregases from yeast and humans. PLOS Biology 10:e1001346. doi: 10.1371/journal. pbio.1001346.

Eaglestone SS, Cox BS, Tuite MF. 1999. Translation termination efficiency can be regulated in Saccharomyces cerevisiae by environmental stress through a prion-mediated mechanism. The EMBO Journal 18:1974-1981. doi: 10.1093/emboj/18.7.1974.

Eaglestone SS, Ruddock LW, Cox BS, Tuite MF. 2000. Guanidine hydrochloride blocks a critical step in the propagation of the prion-like determinant $\left[\mathrm{PSI}^{+}\right]$of Saccharomyces cerevisiae. Proceedings of the National Academy of Sciences of USA 97:240-244. doi: 10.1073/pnas.97.1.240.

Erjavec N, Cvijovic M, Klipp E, Nyström T. 2008. Selective benefits of damage partitioning in unicellular systems and its effects on aging. Proceedings of the National Academy of Sciences of USA 105:18764-18769. doi: 10.1073/pnas.0804550105.

Erjavec N, Larsson L, Grantham J, Nyström T. 2007. Accelerated aging and failure to segregate damaged proteins in Sir2 mutants can be suppressed by overproducing the protein aggregation-remodeling factor Hsp104p. Genes \& Development 21:2410-2421. doi: 10.1101/gad.439307.

Escusa-Toret S, Vonk WI, Frydman J. 2013. Spatial sequestration of misfolded proteins by a dynamic chaperone pathway enhances cellular fitness during stress. Nature Cell Biology 15:1231-1243. doi: 10.1038/ncb2838.

Gasch AP, Spellman PT, Kao CM, Carmel-Harel O, Eisen MB, Storz G, Botstein D, Brown PO. 2000. Genomic expression programs in the response of yeast cells to environmental changes. Molecular Biology of the Cell 11:4241-4257. doi: 10.1091/mbc.11.12.4241.

Gidalevitz T, Ben-Zvi A, Ho KH, Brignull HR, Morimoto RI. 2006. Progressive disruption of cellular protein folding in models of polyglutamine diseases. Science 311:1471-1474. doi: 10.1126/science.1124514.

Glover JR, Kowal AS, Schirmer EC, Patino MM, Liu JJ, Lindquist S. 1997. Self-seeded fibers formed by Sup35, the protein determinant of [PSI+], a heritable prion-like factor of S. cerevisiae. Cell 89:811-819. doi: 10.1016/ S0092-8674(00)80264-0.

Grimminger V, Richter K, Imhof A, Buchner J, Walter S. 2004. The prion curing agent guanidinium chloride specifically inhibits ATP hydrolysis by Hsp104. The Journal of Biological Chemistry 279:7378-7383. doi: 10.1074/jbc.M312403200.

Hernebring M, Brolen G, Aguilaniu H, Semb H, Nyström T. 2006. Elimination of damaged proteins during differentiation of embryonic stem cells. Proceedings of the National Academy of Sciences of USA 103 7700-7705. doi: 10.1073/pnas.0510944103.

Higurashi T, Hines JK, Sahi C, Aron R, Craig EA. 2008. Specificity of the J-protein Sis1 in the propagation of 3 yeast prions. Proceedings of the National Academy of Sciences of USA 105:16596-16601. doi: 10.1073/ pnas.0808934105.

Holmes WM, Klaips CL, Serio TR. 2014. Defining the limits: protein aggregation and toxicity in vivo. Critical Reviews in Biochemistry and Molecular Biology 49:294-303. doi: 10.3109/10409238.2014.914151.

Inoue Y, Taguchi H, Kishimoto A, Yoshida M. 2004. Hsp104 binds to yeast Sup35 prion fiber but needs other factor(s) to sever it. The Journal of Biological Chemistry 279:52319-52323. doi: 10.1074/jbc.M408159200.

Ishihara K, Yamagishi N, Saito Y, Adachi H, Kobayashi Y, Sobue G, Ohtsuka K, Hatayama T. 2003. Hsp105alpha suppresses the aggregation of truncated androgen receptor with expanded CAG repeats and cell toxicity. The Journal of Biological Chemistry 278:25143-25150. doi: 10.1074/jbc.M302975200.

Jahn TR, Radford SE. 2008. Folding versus aggregation: polypeptide conformations on competing pathways. Archives of Biochemistry and Biophysics 469:100-117. doi: 10.1016/j.abb.2007.05.015.

Jana NR, Tanaka M, Wang Gh, Nukina N. 2000. Polyglutamine length-dependent interaction of Hsp40 and Hsp70 family chaperones with truncated $n$-terminal huntingtin: their role in suppression of aggregation and cellular toxicity. Human Molecular Genetics 9:2009-2018. doi: 10.1093/hmg/9.13.2009.

Johnston JA, Ward CL, Kopito RR. 1998. Aggresomes: a cellular response to misfolded proteins. The Journal of Cell Biology 143:1883-1898. doi: 10.1083/jcb.143.7.1883.

Jung G, Jones G, Wegrzyn RD, Masison DC. 2000. A role for cytosolic hsp70 in yeast $\left[P S I^{+}\right]$prion propagation and $\left[\mathrm{PSI}^{+}\right]$as a cellular stress. Genetics 156:559-570.

Jung G, Masison DC. 2001. Guanidine hydrochloride inhibits Hsp104 activity in vivo: a possible explanation for its effect in curing yeast prions. Current Microbiology 43:7-10. doi: 10.1007/s002840010251.

Kaganovich D, Kopito R, Frydman J. 2008. Misfolded proteins partition between two distinct quality control compartments. Nature 454:1088-1095. doi: 10.1038/nature07195. 
Kawai-Noma S, Pack CG, Tsuji T, Kinjo M, Taguchi H. 2009. Single mother-daughter pair analysis to clarify the diffusion properties of yeast prion Sup35 in guanidine-HCl-treated [PSI] cells. Genes to Cells 14:1045-1054. doi: 10.1111/j.1365-2443.2009.01333.x.

Kim YE, Hipp MS, Bracher A, Hayer-Hartl M, Hartl FU. 2013. Molecular chaperone functions in protein folding and proteostasis. Annual Review of Biochemistry 82:323-355. doi: 10.1146/annurev-biochem-060208-092442.

King CY, Tittmann P, Gross H, Gebert R, Aebi M, Wüthrich K. 1997. Prion-inducing domain 2-114 of yeast Sup35 protein transforms in vitro into amyloid-like filaments. Proceedings of the National Academy of Sciences of USA 94:6618-6622. doi: 10.1073/pnas.94.13.6618.

Kirstein-Miles J, Morimoto RI. 2013. Ribosome-associated chaperones act as proteostasis sentinels. Cell Cycle 12:2335-2336. doi: 10.4161/cc.25703.

Knorre DA, Kulemzina IA, Sorokin MI, Kochmak SA, Bocharova NA, Sokolov SS, Severin FF. 2010. Sir2-dependent daughter-to-mother transport of the damaged proteins in yeast is required to prevent high stress sensitivity of the daughters. Cell Cycle 9:4501-4505. doi: 10.4161/cc.9.22.13683.

Kobayashi Y, Kume A, Li M, Doyu M, Hata M, Ohtsuka K, Sobue G. 2000. Chaperones Hsp70 and Hsp40 suppress aggregate formation and apoptosis in cultured neuronal cells expressing truncated androgen receptor protein with expanded polyglutamine tract. The Journal of Biological Chemistry 275:8772-8778. doi: 10.1074/ jbc.275.12.8772.

Kohno H, Tanaka K, Mino A, Umikawa M, Imamura H, Fujiwara T, Fujita Y, Hotta K, Qadota H, Watanabe T, Ohya Y, Takai Y. 1996. Bni1p implicated in cytoskeletal control is a putative target of Rho1p small Gtp binding protein in saccharomyces cerevisiae. The EMBO Journal 15:6060-6068.

Kryndushkin DS, Alexandrov IM, Ter-Avanesyan MD, Kushnirov VV. 2003. Yeast $\left[\mathrm{PSI} \mathrm{I}^{+}\right]$prion aggregates are formed by small Sup35 polymers fragmented by Hsp104. The Journal of Biological Chemistry 278: 49636-49643. doi: 10.1074/jbc.M307996200.

Kummer E, Oguchi Y, Seyffer F, Bukau B, Mogk A. 2013. Mechanism of Hsp104/Clpb inhibition by prion curing Guanidinium Hydrochloride. FEBS Letters 587:810-817. doi: 10.1016/j.febslet.2013.02.011.

Lim Y, Kehm VM, Lee EB, Soper JH, Li C, Trojanowski JQ, Lee VM. 2011. Alpha-Syn suppression reverses synaptic and memory defects in a mouse model of dementia with Lewy bodies. The Journal of Neuroscience 31: 10076-10087. doi: 10.1523/JNEUROSCI.0618-11.2011.

Lindquist SL, Kelly JW. 2011. Chemical and biological approaches for adapting proteostasis to ameliorate protein misfolding and aggregation diseases: progress and prognosis. Cold Spring Harbor Perspectives in Biology 3:a004507. doi: 10.1101/cshperspect.a004507.

Liu B, Larsson L, Caballero A, Hao X, Oling D, Grantham J, Nyström T. 2010. The polarisome is required for segregation and retrograde transport of protein aggregates. Cell 140:257-267. doi: 10.1016/j.cell.2009.12.031.

Lo Bianco C, Shorter J, Regulier E, Lashuel H, Iwatsubo T, Lindquist S, Aebischer P. 2008. Hsp104 antagonizes alpha-synuclein aggregation and reduces dopaminergic degeneration in a rat model of Parkinson disease. The Journal of Clinical Investigation 118:3087-3097. doi: 10.1172/JCI35781.

Malinovska L, Kroschwald S, Munder MC, Richter D, Alberti S. 2012. Molecular chaperones and stress-inducible protein-sorting factors coordinate the spatiotemporal distribution of protein aggregates. Molecular Biology of the Cell 23:3041-3056. doi: 10.1091/mbc.E12-03-0194.

Mallucci G, Dickinson A, Linehan J, Klohn PC, Brandner S, Collinge J. 2003. Depleting neuronal PrP in prion infection prevents disease and reverses spongiosis. Science 302:871-874. doi: 10.1126/science.1090187302/5646/871.

Mattoo RU, Sharma SK, Priya S, Finka A, Goloubinoff P. 2013. Hsp110 is a bona fide chaperone using ATP to unfold stable misfolded polypeptides and reciprocally collaborate with $\mathrm{Hsp} 70$ to solubilize protein aggregates. The Journal of Biological Chemistry 288:21399-21411. doi: 10.1074/jbc.M113.479253.

Meriin AB, Zhang X, Miliaras NB, Kazantsev A, Chernoff YO, McCaffery JM, Wendland B, Sherman MY. 2003. Aggregation of expanded polyglutamine domain in yeast leads to defects in endocytosis. Molecular and Cellular Biology 23:7554-7565. doi: 10.1128/MCB.23.21.7554-7565.2003.

Morimoto RI. 2008. Proteotoxic stress and inducible chaperone networks in neurodegenerative disease and aging. Genes \& Development 22:1427-1438. doi: 10.1101/gad.1657108.

Morimoto RI. 2011. The heat shock response: systems biology of proteotoxic stress in aging and disease. Cold Spring Harbor Symposia on Quantitative Biology 76:91-99. doi: 10.1101/sqb.2012.76.010637.

Ness F, Ferreira P, Cox BS, Tuite MF. 2002. Guanidine hydrochloride inhibits the generation of prion "seeds" but not prion protein aggregation in yeast. Molecular and Cellular Biology 22:5593-5605. doi: 10.1128/ MCB.22.15.5593-5605.2002.

Newnam GP, Birchmore JL, Chernoff YO. 2011. Destabilization and recovery of a yeast prion after mild heat shock. Journal of Molecular Biology 408:432-448. doi: 10.1016/j.jmb.2011.02.034.

Olzscha H, Schermann SM, Woerner AC, Pinkert S, Hecht MH, Tartaglia GG, Vendruscolo M, Hayer-Hartl M, Hartl FU, Vabulas RM. 2011. Amyloid-like aggregates sequester numerous metastable proteins with essential cellular functions. Cell 144:67-78. doi: 10.1016/j.cell.2010.11.050.

Park SH, Kukushkin Y, Gupta R, Chen T, Konagai A, Hipp MS, Hayer-Hartl M, Hartl FU. 2013. PolyQ proteins interfere with nuclear degradation of cytosolic proteins by sequestering the Sis $1 p$ chaperone. Cell 154: 134-145. doi: 10.1016/j.cell.2013.06.003.

Park YN, Zhao X, Yim YI, Todor H, Ellerbrock R, Reidy M, Eisenberg E, Masison DC, Greene LE. 2014. Hsp104 overexpression cures Saccharomyces cerevisiae $\left[\mathrm{PSI}^{+}\right]$by causing dissolution of the prion seeds. Eukaryotic Cell 13:635-647. doi: 10.1128/EC.00300-13.

Patino MM, Liu JJ, Glover JR, Lindquist S. 1996. Support for the prion hypothesis for inheritance of a phenotypic trait in yeast. Science 273:622-626. doi: 10.1126/science.273.5275.622. 
Paushkin SV, Kushnirov VV, Smirnov VN, Ter-Avanesyan MD. 1996. Propagation of the yeast prion-like [PSI+] determinant is mediated by oligomerization of the Sup35-encoded polypeptide chain release factor. The EMBO Journal 15:3127-3134.

Pezza JA, Langseth SX, Raupp Yamamoto R, Doris SM, Ulin SP, Salomon AR, Serio TR. 2009. The Nata acetyltransferase couples Sup35 prion complexes to the $\left[\mathrm{PSI}^{+}\right]$phenotype. Molecular Biology of the Cell 20: 1068-1080. doi: 10.1091/mbc.E08-04-0436.

Powers ET, Morimoto RI, Dillin A, Kelly JW, Balch WE. 2009. Biological and chemical approaches to diseases of proteostasis deficiency. Annual Review of Biochemistry 78:959-991. doi: 10.1146/annurev.biochem.052308.114844.

Rampelt H, Kirstein-Miles J, Nillegoda NB, Chi K, Scholz SR, Morimoto RI, Bukau B. 2012. Metazoan Hsp70 machines use Hsp110 to power protein disaggregation. The EMBO Journal 31:4221-4235. doi: 10.1038/ emboj.2012.264.

Rujano MA, Bosveld F, Salomons FA, Dijk F, van Waarde MA, van der Want JJ, de Vos RA, Brunt ER, Sibon OC, Kampinga HH. 2006. Polarised asymmetric inheritance of accumulated protein damage in higher eukaryotes. PLOS Biology 4:e417. doi: 10.1371/journal.pbio.0040417.

Sanchez Y, Taulien J, Borkovich KA, Lindquist S. 1992. Hsp104 is required for tolerance to many forms of stress. The EMBO Journal 11:2357-2364.

Satpute-Krishnan P, Langseth SX, Serio TR. 2007. Hsp104-dependent remodeling of prion complexes mediates protein-only inheritance. PLOS Biology 5:e24. doi: 10.1371/journal.pbio.0050024.

Satpute-Krishnan P, Serio TR. 2005. Prion protein remodelling confers an immediate phenotypic switch. Nature 437:262-265. doi: 10.1038/nature03981.

Schaffar G, Breuer P, Boteva R, Behrends C, Tzvetkov N, Strippel N, Sakahira H, Siegers K, Hayer-Hartl M, Hartl FU. 2004. Cellular toxicity of polyglutamine expansion proteins: mechanism of transcription factor deactivation. Molecular Cell 15:95-105. doi: 10.1016/j.molcel.2004.06.029.

Serio TR, Cashikar AG, Kowal AS, Sawicki GJ, Moslehi JJ, Serpell L, Arnsdorf MF, Lindquist SL. 2000. Nucleated conformational conversion and the replication of conformational information by a prion determinant. Science 289:1317-1321. doi: 10.1126/science.289.5483.1317.

Shorter J. 2011. The mammalian disaggregase machinery: Hsp110 synergizes with $\mathrm{Hsp} 70$ and Hsp40 to catalyze protein disaggregation and reactivation in a cell-free system. PLOS ONE 6:e26319. doi: 10.1371/journal. pone.0026319.

Shorter J, Lindquist S. 2004. Hsp104 catalyzes formation and elimination of self-replicating Sup35 prion conformers. Science 304:1793-1797. doi: 10.1126/science.1098007.

Shorter J, Lindquist S. 2008. Hsp104, Hsp70 and Hsp40 interplay regulates formation, growth and elimination of Sup35 prions. The EMBO Journal 27:2712-2724. doi: 10.1038/emboj.2008.194.

Song Y, Wu YX, Jung G, Tutar Y, Eisenberg E, Greene LE, Masison DC. 2005. Role for Hsp70 chaperone in Saccharomyces cerevisiae prion seed replication. Eukaryotic Cell 4:289-297. doi: 10.1128/EC.4.2.289-297.2005.

Specht S, Miller SB, Mogk A, Bukau B. 2011. Hsp42 is required for sequestration of protein aggregates into deposition sites in saccharomyces cerevisiae. The Journal of Cell Biology 195:617-629. doi: 10.1083/jcb.201106037.

Spokoini R, Moldavski O, Nahmias Y, England JL, Schuldiner M, Kaganovich D. 2012. Confinement to organelleassociated inclusion structures mediates asymmetric inheritance of aggregated protein in budding yeast. Cell Reports 2:738-747. doi: 10.1016/j.celrep.2012.08.024.

Tam S, Geller R, Spiess C, Frydman J. 2006. The chaperonin TRiC controls polyglutamine aggregation and toxicity through subunit-specific interactions. Nature Cell Biology 8:1155-1162. doi: 10.1038/ncb1477.

Tanaka M, Collins SR, Toyama BH, Weissman JS. 2006. The physical basis of how prion conformations determine strain phenotypes. Nature 442:585-589. doi: 10.1038/nature04922.

Tariq M, Wegrzyn R, Anwar S, Bukau B, Paro R. 2013. Drosophila GAGA factor polyglutamine domains exhibit prion-like behavior. BMC Genomics 14:374. doi: 10.1186/1471-2164-14-374.

Taylor RC, Dillin A. 2011. Aging as an event of proteostasis collapse. Cold Spring Harbor Perspectives in Biology 3:a004440. doi: 10.1101/cshperspect.a004440.

Ter-Avanesyan MD, Kushnirov VV, Dagkesamanskaya AR, Didichenko SA, Chernoff YO, Inge-Vechtomov SG, Smirnov VN. 1993. Deletion analysis of the Sup35 gene of the yeast Saccharomyces cerevisiae reveals two non-overlapping functional regions in the encoded protein. Molecular Microbiology 7:683-692. doi: 10.1111/ j.1365-2958.1993.tb01159.x.

Tessarz P, Schwarz M, Mogk A, Bukau B. 2009. The yeast AAA+ chaperone Hsp104 is part of a network that links the actin cytoskeleton with the inheritance of damaged proteins. Molecular and Cellular Biology 29:3738-3745. doi: 10.1128/MCB.00201-09.

Tipton KA, Verges KJ, Weissman JS. 2008. In vivo monitoring of the prion replication cycle reveals a critical role for Sis1 in delivering substrates to Hsp104. Molecular Cell 32:584-591. doi: 10.1016/j.molcel.2008.11.003.

Torrente MP, Shorter J. 2013. The metazoan protein disaggregase and amyloid depolymerase system: Hsp110, Hsp70, Hsp40, and small heat shock proteins. Prion 7:457-463. doi: 10.4161/pri.27531.

Tuite MF, Mundy CR, Cox BS. 1981. Agents that cause a high frequency of genetic change from [PSI+ $]$ to [psi $]$ in Saccharomyces cerevisiae. Genetics 98:691-711.

Tuite MF, Serio TR. 2010. The prion hypothesis: from biological anomaly to basic regulatory mechanism. Nature Reviews Molecular Cell Biology 11:823-833. doi: 10.1038/nrm3007.

Unal E, Kinde B, Amon A. 2011. Gametogenesis eliminates age-induced cellular damage and resets life span in yeast. Science 332:1554-1557. doi: 10.1126/science.1204349.

Voisine C, Pedersen JS, Morimoto RI. 2010. Chaperone networks: tipping the balance in protein folding diseases. Neurobiology of Disease 40:12-20. doi: 10.1016/j.nbd.2010.05.007. 
Wang J, Farr GW, Zeiss CJ, Rodriguez-Gil DJ, Wilson JH, Furtak K, Rutkowski DT, Kaufman RJ, Ruse Cl, Yates JR III, Perrin S, Feany MB, Horwich AL. 2009. Progressive aggregation despite chaperone associations of a mutant SOD1-YFP in transgenic mice that develop ALS. Proceedings of the National Academy of Sciences of USA 106:1392-1397. doi: 10.1073/pnas.0813045106.

Wegrzyn RD, Bapat K, Newnam GP, Zink AD, Chernoff YO. 2001. Mechanism of prion loss after Hsp104 inactivation in yeast. Molecular and Cellular Biology 21:4656-4669. doi: 10.1128/MCB.21.14.4656-4669.2001.

Weisberg SJ, Lyakhovetsky R, Werdiger AC, Gitler AD, Soen Y, Kaganovich D. 2012. Compartmentalization of superoxide dismutase 1 (SOD1G93A) aggregates determines their toxicity. Proceedings of the National Academy of Sciences of USA 109:15811-15816. doi: 10.1073/pnas.1205829109.

Winkler J, Tyedmers J, Bukau B, Mogk A. 2012. Hsp70 targets Hsp100 chaperones to substrates for protein disaggregation and prion fragmentation. The Journal of Cell Biology 198:387-404. doi: 10.1083/jcb.201201074.

Wolfe KJ, Ren HY, Trepte P, Cyr DM. 2013. The Hsp70/90 cochaperone, Sti1, suppresses proteotoxicity by regulating spatial quality control of amyloid-like proteins. Molecular Biology of the Cell 24:3588-3602. doi: 10.1091/mbc.E13-06-0315.

Wolff S, Weissman JS, Dillin A. 2014. Differential scales of protein quality control. Cell 157:52-64. doi: 10.1016/j. cell.2014.03.007.

Yamamoto A, Lucas JJ, Hen R. 2000. Reversal of neuropathology and motor dysfunction in a conditional model of huntington's disease. Cell 101:57-66. doi: 10.1016/S0092-8674(00)80623-6.

Yang Z, Hong JY, Derkatch IL, Liebman SW. 2013. Heterologous gln/asn-rich proteins impede the propagation of yeast prions by altering chaperone availability. PLOS Genetics 9:e1003236. doi: 10.1371/journal.pgen.1003236.

Yu A, Shibata Y, Shah B, Calamini B, Lo DC, Morimoto RI. 2014. Protein aggregation can inhibit clathrin-mediated endocytosis by chaperone competition. Proceedings of the National Academy of Sciences of USA 111: E1481-E1490. doi: 10.1073/pnas.1321811111.

Zeymer C, Werbeck ND, Schlichting I, Reinstein J. 2013. The molecular mechanism of Hsp100 chaperone inhibition by the prion curing agent guanidinium chloride. The Journal of Biological Chemistry 288:7065-7076. doi: 10.1074/jbc.M112.432583.

Zhou C, Slaughter BD, Unruh JR, Eldakak A, Rubinstein B, Li R. 2011. Motility and segregation of Hsp104associated protein aggregates in budding yeast. Cell 147:1186-1196. doi: 10.1016/j.cell.2011.11.002. 